IZA DP No. 10067

On the Boundaries of the Shadow Economy: An Empirical Investigation

Eran Manes

Friedrich Schneider

Anat Tchetchik

July 2016 


\title{
On the Boundaries of the Shadow Economy: An Empirical Investigation
}

\author{
Eran Manes \\ Lev Institute of Technology \\ Friedrich Schneider \\ Johannes Kepler University of Linz \\ and IZA \\ Anat Tchetchik \\ Ben-Gurion University
}

Discussion Paper No. 10067

July 2016

IZA

P.O. Box 7240

53072 Bonn

Germany

Phone: +49-228-3894-0

Fax: +49-228-3894-180

E-mail: iza@iza.org

Any opinions expressed here are those of the author(s) and not those of IZA. Research published in this series may include views on policy, but the institute itself takes no institutional policy positions. The IZA research network is committed to the IZA Guiding Principles of Research Integrity.

The Institute for the Study of Labor (IZA) in Bonn is a local and virtual international research center and a place of communication between science, politics and business. IZA is an independent nonprofit organization supported by Deutsche Post Foundation. The center is associated with the University of Bonn and offers a stimulating research environment through its international network, workshops and conferences, data service, project support, research visits and doctoral program. IZA engages in (i) original and internationally competitive research in all fields of labor economics, (ii) development of policy concepts, and (iii) dissemination of research results and concepts to the interested public.

IZA Discussion Papers often represent preliminary work and are circulated to encourage discussion. Citation of such a paper should account for its provisional character. A revised version may be available directly from the author. 


\title{
ABSTRACT \\ On the Boundaries of the Shadow Economy: An Empirical Investigation
}

\begin{abstract}
A large number of empirical studies pointed to the ongoing expansion of the shadow economy in many countries around the globe. A robust finding in these studies is the positive association between unemployment rates and the size of the unofficial sector. However, with consistent estimates of the size of the unofficial sector only available from the late 1980s, a lack of sufficient time span dictated the use of static models, allowing only a limited understanding of its temporal behavior and interdependence with other covariates. In this paper, we offer a first systematic attempt to estimate the dynamics of the shadow economy, using advanced dynamic panel techniques. Based on insights from a simple job search model of unemployment that features decreasing returns to unofficial activities and congestion effects in job searching, we conjecture a long-run equilibrium relationship between unemployment and the size of the shadow economy. Our empirical model lends strong support to this view. We find that in countries with less stringent job market regulation the long-run impact of Unemployment, the tax burden, and GDP on the shadow economy, while positive and significant, is much smaller than in heavily regulated countries Moreover, the speed of adjustment back to long-run equilibrium following temporary shocks is shown to be three times faster in countries with looser job-market regulation, compared with countries with stricter regulation. These findings have important policy implications.
\end{abstract}

JEL Classification: $\quad$ C32, H11, H26, I2, O17, P16, P48

Keywords: shadow economy, boundaries to the shadow economy, unemployment, taxation, regulation

Corresponding author:

Friedrich Schneider

Department of Economics

Johannes Kepler University of Linz

Altenbergerstr. 69

4040 Linz

Austria

E-mail: friedrich.schneider@jku.at 


\section{Introduction}

Exploring the causes for the rapid world-wide expansion of the shadow economy, and its cross-country variation, has been the focus of many empirical studies, ever since a systematic estimation of the size of the unofficial sector has become available. A consistent empirical finding in many of these studies is the positive association between the unemployment rate and the size of the shadow economy (Enste 2003, Dell'Anno and Solomon 2008, Bajada \& Schneider 2009, Schneider 2011, Schneider and Williams 2013, and Williams and Schneider 2016). The main idea advanced in these papers is that the shadow economy acts as a buffer, absorbing a portion of the laid off workers from the official economy following negative jobmarket shocks. A major related question, however, seems to be begging an answer: Is this absorption temporary or permanent? In other words, do workers who switch to the unofficial sector, following adverse temporary shocks, switch back to active job search (and eventually to the official job market itself) or do they stay "locked in" in the unofficial sector? One cannot overestimate the importance of this question. If the shadow economy is only a temporary buffer, then there should be a long-run and steady relationship between unemployment and the size of the unofficial sector, wherein adverse temporary shocks that result in the unofficial sector "stealing" workers from the legitimate work force are gradually reversed by the working of restoring economic forces. If, on the other hand, the shadow economy is an absorbing state, then the growth of unemployment rates that has been witnessed in many European economies and elsewhere over the last decades is a real cause for concern.

The answer to this important question appears, at first glance, to be in favor of the shadow economy being an absorbing state, in light of the constant growth of the shadow economy, recorded in many countries over the 1980's and 1990's. The beginning of the current millennium, however, marks itself as a major tipping point (see S1 for the tipping point distribution in 97 countries). As can be seen in Figure 1.1, the unofficial sector started shrinking around that time in many economies (left panel), and what appears to be a consistent co-movement between unemployment rates and the size of the unofficial economy started taking place (right panel). 


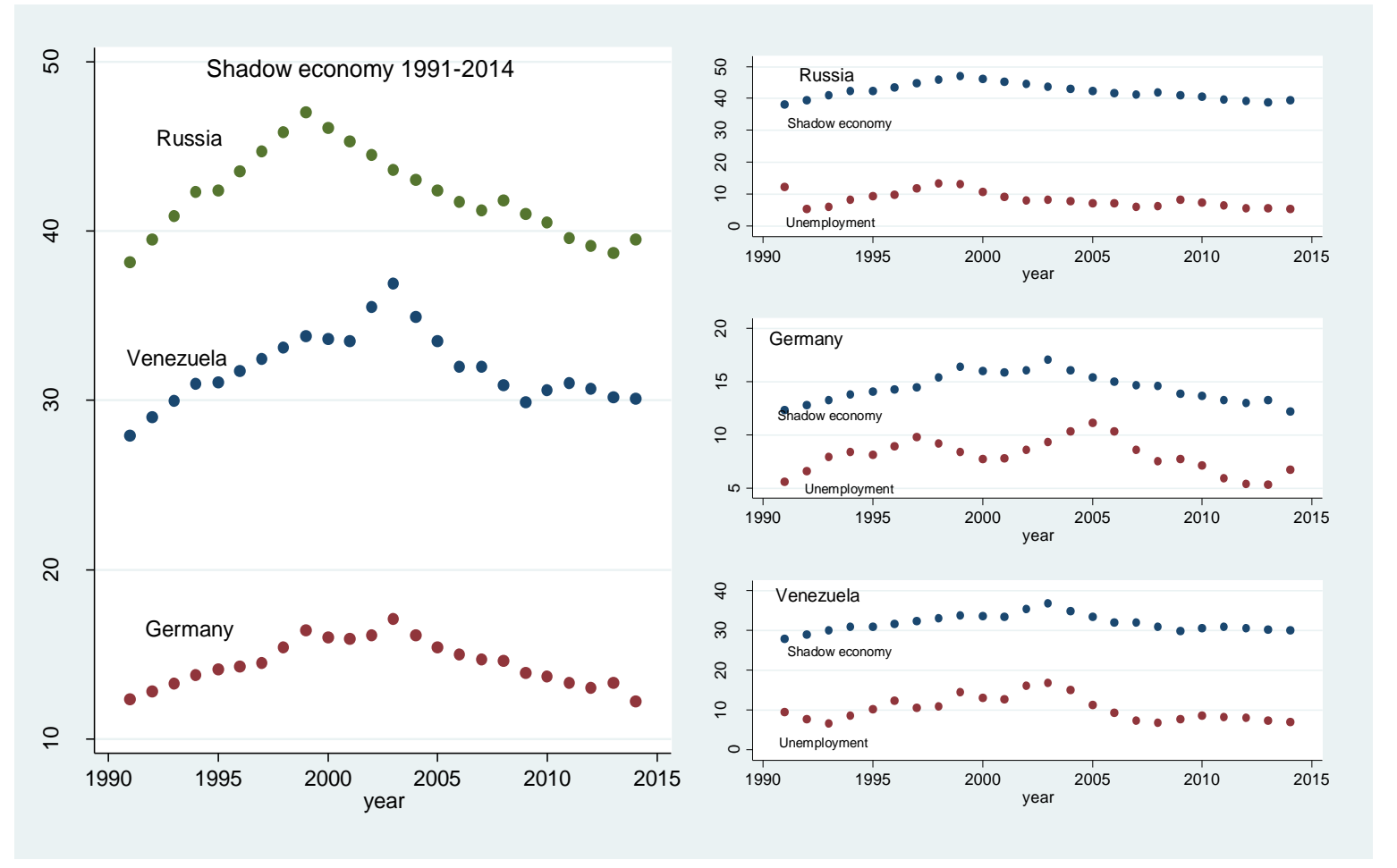

Figure 1.1: The behavior of the shadow economy and unemployment in selected countries

The main purpose of this paper, in light of these findings, is to entertain, both empirically and theoretically, the idea that there exists an error-correction mechanism that binds these two variables to a long-run equilibrium relationship. As we discuss below, studying this mechanism has important policy implications.

An important aspect of unofficial activities, which has been overlooked by most of the literature up to date, is its strong "social" dependence, and the possible existence of increasing returns due to network externalities and strategic complementarities, on the one hand, and decreasing returns due to congestion effects on the other hand. Strategic complementarities and network externalities are similar notions; roughly speaking, and while ignoring differences related to strategic issues such as coordination problems and formation of expectations, both relate to economic activities where private returns are increasing with the mass of individuals involved in these activities. Well-known examples range from participation in riots and revolutions, team effort, the use of communication technologies, and investment in human capital, to name just a few. As unofficial activities take place "under the radar" they entail trust between different parties to the (illicit) transaction (D'Hernoncourt \& Méon 2012) and they strongly rely on informal connections and the minimization of search 
costs, which might be facilitated with the expansion of this sector. ${ }^{1}$ These considerations give rise, therefore, to the conjecture that, at least in some range, the unofficial sector is characterized with network externalities and hence with increasing returns. Yet, diminishing returns may set in at some point due to congestion effects, which are the result of intensified competition in the unofficial sector for "moonlighting" income sources, and the shrinkage of the official economy which goes hand in hand with the expansion of the underground economy (this is the "income effect" mentioned in Bajada \& Schneider 2009).

In Section II we develop a simple model in which we analyze the conditions under which a stable, long-run relationship between unemployment and the size of the shadow economy is present, and which features the elements mentioned above. While switches from employment to unemployment occurs randomly in the model, once out of job, workers have to choose between actively searching for a vacancy, or joining the unofficial sector, thereby giving up the option of finding a job, at least temporarily. As the textbook definition of unemployment status applies to individuals (mentally and physically available for working) who actively search for a job (yet cannot find one), we refer to individuals who favor the first choice as unemployed, and to those opting for the second choice as belonging to the unofficial sector. The analysis demonstrates that in economies where increasing returns (due to network externalities) exhaust themselves relatively fast, the equilibrium size of the shadow economy will be relatively small, and the long-run relationship between unemployment and the size of the shadow economy will be bound by an error-correction mechanism. The important condition being directly responsible for this result is the presence of local decreasing returns in the unofficial sector, in the vicinity of equilibrium, coupled with congestion effects in job searching. The underlying intuition is straightforward; consider a temporary negative shock that results in the termination of jobs at a rate higher than expected. With now greater mass of unemployed, congestion effects in job searching implies that the probability of finding a job is smaller, hence the value of actively searching for a job (which is the sum of unemployment benefits and the value of the real option associated with job search that yields "capital gains" in the event of finding a job) falls. This triggers a switch, at the margin, from unemployment to the unofficial sector. With decreasing returns, ${ }^{2}$ though, this switch is reversible; as private returns for engaging in unofficial activities decline with the size of this sector, a switch back

\footnotetext{
${ }^{1}$ This argument may go either way. Enhanced trust may accompany both a small or relatively large unofficial sector.

${ }^{2}$ In fact, as the analysis in the next section shows, even local increasing returns are sufficient for stability, as long as they do not rise "too fast" and that job searching is characterized with congestion effects.
} 
to active job search takes place once conditions are reversed. With increasing returns, however, there is likely to be a multiplicity of equilibria, in which case even small and temporary shocks can move the system away from one equilibrium to another.

The model we suggest in Section II is by no means the sole explanation for the temporal behavior exhibited by the shadow economy around the globe in recent decays. Indeed, a modelling approach in the spirit of well-known tax evasion models may be suitable here too. For example, in Yitzhaki (1987) the extent of tax evasion by risk-neutral agents is constrained by the (endogenous) positive adjustment of the probability of detection to increases in evaded income. Similarly, a modeling approach that ties the (private) benefit from unofficial activities to culturally dependent attributes such as tax moral and disutility from dishonest behavior are also fully legitimate here. While our model can easily incorporate such elements as risk aversion and enforcement policy, we feel that such micro-founded approach is unwarranted here. This is mainly due to the fact that while these models are concerned with rationalizing the tax evasion choices of individuals and their response to policy instruments (such as tax rates and auditing policy), we care more for the joint determination of the extent of overall unofficial activities and the size of unemployment, and its response to temporary shocks that lead to spontaneous moves away from the official sector. In addition, our model makes no statement as to which causes are responsible for having increasing or rather decreasing returns. Instead, it simply identifies the non-absorptive attribute of the unofficial sector with local decreasing returns, coupled with congestion effects in the job-searching process. ${ }^{3}$ A more elaborate approach may try to derive the qualitative characteristics of the private returns from engaging in unofficial activities from microeconomic foundations.

Our model puts forward several important, testable hypotheses; (I) The unemployment rate and the shadow economy are bound to a long-run equilibrium relationship by an errorcorrection mechanism. (II) The long-run impact of Unemployment on the shadow economy is much smaller in countries with less stringent job market regulation while than in heavily regulated countries and (III) the speed of adjustment back to equilibrium is greater in economies with looser job market regulation, compared with countries where regulation of employer-employee relationship is stricter. These hypotheses have important policy

\footnotetext{
${ }^{3}$ Congestion effect in job searching simply maintains that the equilibrium probability of finding a job increases with the rate of employment and declines with the rate of unemployment. This attribute is common to many search models of unemployment. As the model in the next section demonstrates, congestion effects in job searching imply that the private cost of belonging to the unofficial sector rises with its size. As we show, a necessary and sufficient condition for stable equilibrium is that the marginal cost is steeper than the marginal benefit in the vicinity of equilibrium.
} 
implications. While the first of them may deliver a positive message, implying that the growth of the unofficial sector is bounded, and that laid- off workers do eventually return to the official job market (even if temporarily drawn to the unofficial sector), the other two hypotheses point both to the drawn out nature of the process of moving back from the shadow economy, and the strong dependence of this adjustment back to equilibrium on job market regulation. In that respect, our paper is related to a large body of empirical and theoretical literature that seeks to explore the effect of the severity of job market regulation on job market turnover rates (see Heckman and Pages (2000) for an in-depth survey of the empirical literature). Our paper contributes to this literature by confirming the view that stricter job market regulation makes it harder to switch back from the unofficial to the official sector.

Empirically, an effort to test our hypotheses entails framing the empirical model within a dynamic, rather than static, panel. In that respect, our paper is a first attempt to model the relationship between unemployment and the shadow economy within a dynamic setup. Given the many advancements made in the estimation of dynamic panel models, and their inherent ability to explicitly distinguish between the short and long run effects, and with the accumulation of long enough time span of shadow economy estimation, we believe that the findings presented in Figure 1.1, warrant this approach. We pursue this modeling strategy in the empirical sections of the paper. Using a panel dataset that spans the period 1991-2014 and includes 47 countries, we estimate an error-correction specification, while including - in addition to our central variables of interest (unemployment and shadow economy) a set of covariates known from previous studies to affect the size of the shadow economy. While we discuss the results and related methodological issues in further detail below, on balance, our results lend strong support to the theoretical predictions.

Previous empirical studies (see the references mentioned above) have already established that the shadow economy acts as a buffer as it absorbs some of the unemployed workers from the official economy following negative job market shocks. Hence, the association between a rising unemployment and the growth of the shadow economy reported in several studies (Enste 2003, Dell'Anno and Solomon 2008). With no exception, however, these papers employed static models, at least partially due to the lack of sufficiently long time series data for the shadow economy. Moreover, none of these papers focused on the possibility of switches back from the unofficial into the official sector, arguably because the former exhibited a constant expansionary trend ever since estimations of its size have become available. The apparent co-movement that seems to follow from Figure 1.1, calls upon the use 
of dynamic panel models, which, unlike static models, are capable of isolating the long run from the short run effects. Moreover, reparametrized in error-correction form, such models can give indication as for the convergence path, following transitory shocks that these comoving pair follows, while adjusting back to equilibrium. Altogether, therefore, our approach offers an important point of departure from existing literature, in its novel view of the dynamic evolution of the shadow economy and its tendency to co-integrate with important economic covariates.

The rest of the paper is organized as follows: in Section II we present a simple model that captures the nature of the moves from unemployment to the unofficial sector, and the forces leading this process to restore itself. We end this section with presenting our main hypotheses. In Section III we present the dataset and discuss our econometric approach while addressing methodological issues in detail. Section IV presents our main results, while Section V discusses policy implications and offers the conclusion of the paper.

\section{The Model}

\section{II.1 Basic Setup}

We consider an infinitely lived economy with many employers and workers. The labor force is stationary and its size is normalized to be of unit mass. Each worker, at every instant $t$, can be either employed or unemployed. If employed, workers earn a time invariant wage - $w$. There is however a job destruction process, where the probability of an employed worker to lose his job, at every instant $t$, equals $d$, which we take as fully exogenous parameter. The assumption that job destruction (and creation, see below) follows a Poisson process is common in models that employ dynamic programming principles as it considerably simplifies the analytics.

If unemployed, individuals in our model must decide whether "to stay on the shelf", i.e. sign up as unemployed while actively searching for a vacancy, or enter the unofficial sector, giving up the option to search actively for a job, at least temporarily. We denote with $k \geq 0$ the stream of unemployment benefits (net of job search costs) an unemployed worker receives in every period in the former case. The job creation rate is also assumed to follow a Poisson process. We denote this rate with $a>0$. This quantity is determined endogenously in equilibrium, matching the flow in and out of employment, as we discuss below. 
Upon entering the unofficial sector, the private return from engaging in unofficial activities depends on the size of the unofficial sector, $s \in[0,1]$. We denote this private return with $y(s)$. Clearly, this formulation captures the idea that engaging in unofficial activities is likely to be characterized with either increasing returns $\left(y_{s}>0\right)$ due to network externalities, or decreasing returns $\left(y_{s} \leq 0\right)$. Roughly speaking, the former effect arises whenever private returns from a given activity rise with the mass of individuals engaging in this activity. This effect will dominate whenever there are strong "network externalities" - a greater unofficial sector facilitates "under the radar" matching, enhances trust and lowers search and transaction costs. The second effect will dominate whenever competition and congestion effects in the unofficial sector start playing bigger role. While it may be argued that $y(s)$ is likely to follow an S-curve shape, exhibiting strong strategic complementarities and network externalities in earlier stages, followed by a phase of congestion and strong competition, we remain agnostic over the global shape of this process. Notwithstanding, our analysis will crucially depend on the local attributes of this process in the vicinity of equilibrium, as we discuss this in further detail below.

Let $U=\int_{t=0}^{\infty} e^{-r t} u(t) d t$ be the lifetime discounted utility of workers, where $r$ is a discount factor, and where the instantaneous utility function $u(t)$ equals $w$ if the worker is employed, $k$ if unemployed, and $y(s)$ if the worker is engaged in unofficial activities.

We proceed next by exploiting the principles of dynamic programming: we first calculate $V_{e}, V_{u}, V_{s}$ - the values of being employed, unemployed and engaged in unofficial activities, respectively. We then use equilibrium switching conditions to derive the equilibrium size of the shadow economy, $s^{*}$.

We start with $V_{e}$ : the value of being employed is made off a "dividend stream" of size $w$, the going wage, plus a possible capital loss, associated with a forced switch from employment to unemployment (which occurs with probability $d$ ), i.e.

$$
r V_{e}=w-d\left(V_{e}-V_{u}\right)
$$

Similarly, $V_{u}$, the value of being unemployed, equals the stream of unemployment benefits (net of search cost) $k$, plus the value of the real option - finding a job (with probability $a$ ) and receiving a capital gain $V_{e}-V_{u}$ 


$$
r V_{u}=k+a\left(V_{e}-V_{u}\right)
$$

Lastly, the value of being in the unofficial sector is given by

$$
r V_{s}=y(s)
$$

As there are two possible switches in our model: in and out of employment (which occurs randomly, in a manner which is governed by the Poisson process parameter $d$ ), and once unemployed - in and out of the unofficial sector (which individuals are entirely free to choose), we need two equilibrium conditions to fully characterize equilibrium. The first condition directly follows from the fact that workers are free to choose between actively searching for a job (once unemployed) and being engaged in the unofficial sector, hence in equilibrium these values must equal:

$$
V_{u}=V_{s}
$$

The second condition simply maintains that movements in and out of employment must balance out in equilibrium. If $e$ is the mass of employed workers, and $u$ - the mass of unemployed, then this condition reads

$$
a u=d e
$$

Where the LHS of (5) is the flow of workers into employment status, and the RHS is the flow of workers out of employment.

\section{II.2 Solving the model}

We can now use equations (2) and (3) and plug them in condition (4) which yields

$$
\frac{y(s)-k}{a}=\left(V_{e}-V_{u}\right)
$$

On the other hand, subtracting (2) from (1) gives (after rearranging terms)

$$
\frac{w-k}{a+d+r}=\left(V_{e}-V_{u}\right)
$$

Comparing (6) and (7) we arrive at

$$
y\left(s^{*}\right)=k+\frac{a(w-k)}{a+d+r}
$$


Using the notation $\beta \equiv \frac{a}{a+d+r} \in(0,1)$, (8) boils down to

$$
y\left(s^{*}\right)=\beta w+(1-\beta) k
$$

Where $\beta \in(0,1)$. That is, the private return to engaging in unofficial activities is a weighted average of the wage in the official sector, $w$, and unemployment benefits, $k$. Intuitively, if the probability of finding a job, $a$, is positive, then $y\left(s^{*}\right)$ must be greater than $k$, otherwise we have the trivial solution $s^{*}=0$. Similarly, the private return $y\left(s^{*}\right)$ cannot exceed the sum of unemployment benefit $k$ and the expected gain associated with active job searching, otherwise no active job search will ever take place.

Before deriving our main results, note that (5) implies that our model has a degeneracy; indeed, given the value of the exogenous variable $d$, there are infinitely many values for $e, u$ that support a given value of $a$, the equilibrium job creation rate. The source of this degeneracy is obvious though, as we did not explicitly model the demand for labor. As we care less about the determination of equilibrium employment, and more about switches from unemployment to the shadow economy and back, we adopt a partial equilibrium analysis and simply assume that the "natural rate of employment" is $e_{0}$, which is in the interior of the unit interval.

The following results are relatively easy to derive. In all of them we assume that condition (5) holds, i.e. there are congestion effects in job searching $(a(u)$ falls with $u$, or equivalently $a(s)$ rises with $s)$.

Result 1: (i) Assume that $y(s)$ is continuous in (0,1), and exhibits decreasing returns $\left(y_{s}(s) \leq 0\right)$. Assume further that $\lim _{s \rightarrow 0} y(s)=\infty$, and $\lim _{s \rightarrow 1} y(s)=0$. Then given the values of the exogenous parameters $(w, k, d, r)$ and given $e_{0}$, there is a unique steady state solution, $s^{*} \in(0,1)$, to $(8)$.

(ii) If $y(s)$ exhibits increasing returns $\left(y_{s}>0\right)$, then there could be either no steady state, or multiplicity of steady states, as well as unstable equilibria. A necessary condition for an equilibrium to be a steady state is $y_{s}\left(s^{*}\right) \leq \frac{\partial c\left(a\left(s^{*}\right)\right)}{\partial a} \frac{\partial a\left(s^{*}\right)}{\partial s}$ 
Both parts of Result 1 are demonstrated in the following figure

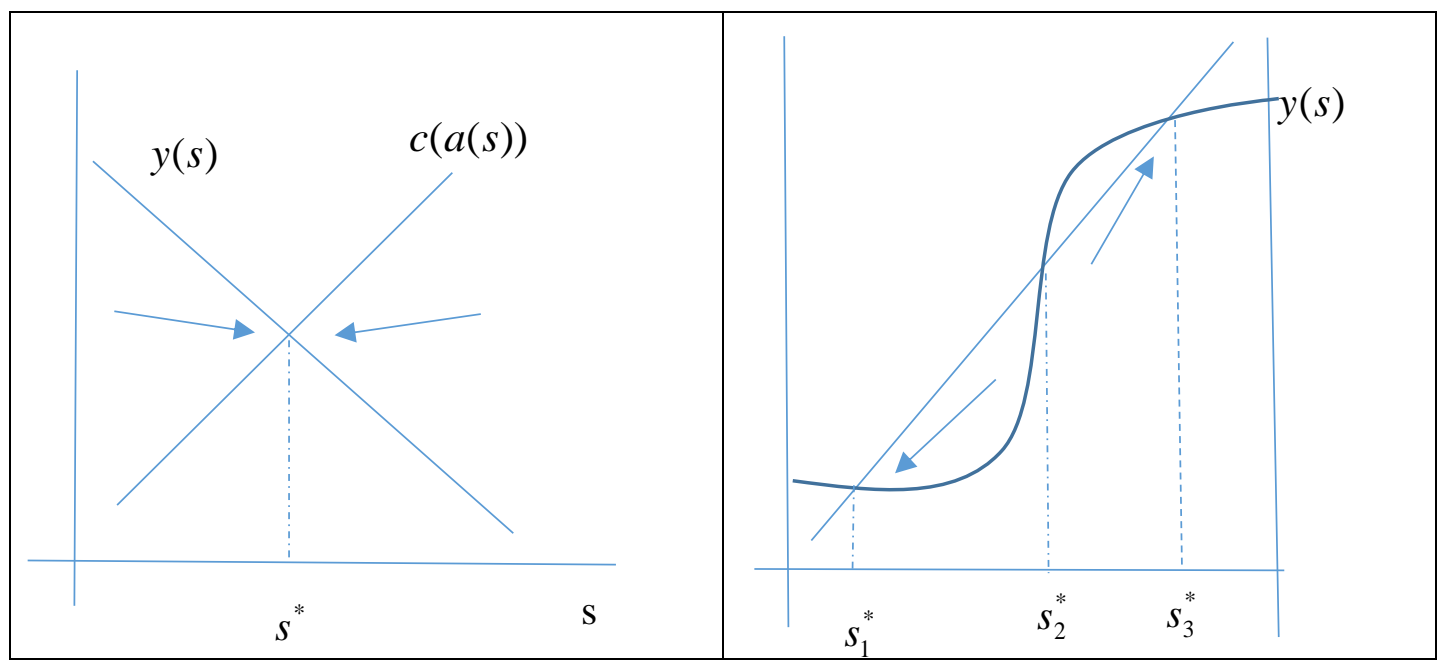

Figure 2.1: Unique steady equilibrium (left panel), and multiple equilibria (right panel)

Note that with decreasing returns, and with the boundary (Inada) conditions imposed, the graph of $y(s)$ is down sloping and must intersect the curve $c(a(s)) \equiv k+\frac{a(w-k)}{a+d+r}$ (which is the RHS of (8)) exactly once. Note further that $c(a(s))$, which measures the private cost of giving up job-search as a function of the size of the unofficial sector, indeed rises with $s$, which is a direct manifestation of congestion effects in job searching: holding $(w, k, d, r)$ fixed, and given $e_{0}$, moving from left to right (raising $s$ ) means that $u$ shrinks (recall that $s+u=1-e_{0}$ ), hence from (5), the equilibrium value of $a$ must rise too. Finally, note that $c(a(s))$ indeed rise with $a$ whenever $w-k>0$.

It is also plain to see that when $y(s)$ has increasing returns (right panel of Figure 2.1), there could be either no equilibria, or multiplicity of equilibria, as the two curves are now sloping up. The nonexistence of equilibrium can be easily dismissed if we further impose a reasonable version of boundary conditions on $y(s)$, more suited to increasing returns, i.e. $y(0)=0$, coupled with the assumption that $a(s=0) \equiv \frac{d e_{0}}{1-e_{0}}>0$, which assures that the RHS of (8) is positive when $s$ approaches zero. 
Of particular interest is the case of multiple equilibria, which requires that the second derivative of $y(s)$ changes sign at least once (See Cooper and John 1988). Note that while $s_{1}^{*}, s_{3}^{*}$ are stable equilibria, $s_{2}^{*}$ is instable. Equilibrium selection therefore features threshold effect, as it depends on initial conditions; if the economy starts below $s_{2}^{*}$ it will converge towards $s_{1}^{*}$, whereas if it starts beyond $s_{2}^{*}$, it will converge to $s_{3}^{*}$. Under such a scenario, temporary shocks may have long-lasting effect, where switching from one equilibrium to another involving lengthy periods of expansion of the unofficial sector.

Result 2: Assume that $y(s)$ exhibits local decreasing returns $\left(y_{s}\left(s^{*}\right) \leq 0\right)$, or alternatively, that $y_{s}\left(s^{*}\right) \geq 0$ and $y_{s}\left(s^{*}\right) \leq \frac{\partial c\left(a\left(s^{*}\right)\right)}{\partial a} \frac{\partial a\left(s^{*}\right)}{\partial s}$, and Let $d$ stands for the exogenous job destruction rate. Then an adverse temporary shock will temporarily raise $s^{*}$, that is $\frac{\partial s^{*}}{\partial d} \geq 0$.

The idea is that an adverse shock to the job market (in the form of a rise in $d$ or a fall in $e_{0}$ ) drives down the expected gain associated with active job search, thus triggering a switch to the informal sector. This explains the co-expansion part of the co-movement of unemployment and the shadow economy. Due to congestion effects in both job searching and unofficial activities, however, this process is reversible. To understand the underlying mechanism, let us recall condition (5), being left unused so far, which states that in equilibrium the flow of unemployed workers into employment status is counterbalanced by the flow of employed workers into unemployment, i.e. $a u=d e$. This condition is equivalent to

$$
a=\frac{d e}{u}
$$

Note that $u$ in the RHS refers only to those unemployed workers who actively search for a job (hence it does not include workers in the unofficial sector). Now consider again a negative shock in the job market such that the RHS of (10) falls temporarily. As we saw in result 1 , this shock will trigger a switch from employment into unemployment, and from unemployment into the unofficial sector, as the expected gain from finding a job falls. This last switch is a direct outcome of congestion effects in job searching. However, a look at (10) reveals the source of the underlying restoring force: the decline in $u$ now causes a rise in $a$, 
which in turn triggers a reverse switch from the shadow economy into active job search (unemployment). This is summarized in the following corollary

Corollary 1: Fix $\left(w, k, e_{0}, r\right)$ and assume that $d_{t}=d_{0}+\varepsilon_{t}$ where $\varepsilon_{t}$ is a zero-mean white noise. Then the time t size of the unofficial sector $s_{t}$ oscillates around the unique steady state solution $s^{*}$ defined in Result 1.

The most important implication of corollary 1 is an empirical one; it implies that the processes $\left\{u_{t}\right\}_{t=0}^{\infty},\left\{s_{t}\right\}_{t=0}^{\infty}$ are co-integrated. This leads to the following hypothesis.

Hypothesis 1: There exists error correction between unemployment and the shadow economy. Hypothesis 1 constitutes our main research question. A second important hypothesis is based on the empirical finding that countries with stricter job market regulations have lower turnover rates. For example, Kugler (2000) studies the effect of the 1990 labor market reforms in Colombia on job-market turnover rates. She reported that a reduction in job security led to a decline in average tenure and an increase in employment exit rates. The decline in average tenure was much greater in the formal sector than in the informal sector (see Heckman and Pages (2000) for a survey of the empirical literature on the effect of job market regulation on labor-market turnover rates).

Hypothesis 2: The speed of adjustment to long-run equilibrium is slower in countries with stricter job market regulation.

We continue next to test these hypotheses.

\section{Methodology}

\section{III.1. Sample}

Data on the size of the SE was collected by Schneider from 1989 for approximately 107 countries (for some countries measuring began at the early 1990s) which constitutes our research population. Data on UE exist for most of these countries for even longer periods. Yet, what limits our sample size is the requirement for countries with sufficiently long time series and with no (or minimal) discrepancies in the data (SE and UE). We eventually choose countries for which data was available for 24 consecutive years (from 1991-2014). S1 lists the 
countries used in the analysis. While these countries constitute our basic sample, in the third stage of the analysis (see the next sub-section), we use additional variables known to affect the size of the SE (e.g. taxation, control of corruption etc.). As a guiding rule, we preferred to employ, as much as possible, reliable data sources (such as the World Bank database). Restricting our data to these sources came at the cost of excluding further countries for which we could not retrieve sufficient time series data.

\section{III.2. Econometric approach}

As this paper studies the long-term relationship between the size of the SE and UE rates, a natural choice was to focus on dynamic panel data models. Static models, such as fixed and random effects models, were not relevant due to their inability to capture the dynamic nature of the data, which is crucial in the context of our study. Such models are incapable of isolating the long-term effects from the short-term ones, and are, therefore, less suited for the purpose of our study. Moreover, the standard fixed effects estimator is inconsistent when the time series dimension of the data is relatively small (Nickell 1981), as is the case with our panel dataset. It is mainly for these reasons that we resort to dynamic panel data models, as described below.

Panel data analysis of unit roots and co-integration have been a prolific area of research over the last two decades (e.g. Levin and Lin (1992, 1993), Quah (1994)). Investigating integrated series in a panel data is the attempt to combine two separate fields; 1 . Unit roots and cointegration in time series, and 2. Panel data econometrics. The rationale for combining these two is that by accounting for the cross-section dimension one can make better inference about the existence of unit roots and co-integration, especially when the time series dimension is not very long, but similar data may be available via a cross-section of units such as countries (Banerjee, 1999).

In order to establish the existence of co-movement between the SE and UE, we followed a 3steps procedure: 1. Conducting unit root tests for our two central variables, SE and UE 2. To the extent that both variables contain unit roots, and are difference stationary, we next conduct the Engle-Granger co-integration test. 3. If co-integration is evident, we can move on to the final analysis: estimation of an error correction model, which is suitable for the estimation of nonstationary heterogeneous panels. We next describe in detail each of the three steps. 


\section{Unit root tests}

Nelson and Plosser's (1982) influential work resulted with a consensus view that most macroeconomic variables have a univariate time-series structure with a unit root. While, to the best of our knowledge, no attempt has been made so far to test for unit root in the size of the $\mathrm{SE}$, the dynamics of unemployment, have gained a lot of attention in the literature. Within the applied macroeconomics literature, many studies explored the behavior of the UE, motivated by several competing hypotheses, with the NAIRU (Non-accelerating inflation rate of unemployment) and the hysteresis hypotheses (which implies that unemployment can be characterized as a random walk) representing two opposing views. This literature includes a series of papers that analyze the order of integration of unemployment rates by means of unit root tests for panel. The results of these studies are mixed. Using data of the EU and OECD, Song \& Wu (1997, 1998) León-Ledesma (2002), Chang et al. (2005) and others find support for the hysteresis hypothesis, whereas Camarero \& Tamarit (2004) found evidence for hysteresis in Austria, Germany, Italy, Japan, Norway and Switzerland, but not in other OECD countries. On the other hand, Christopoulos \& León-Ledesma (2007) find evidence against the hysteresis hypothesis for EU data. Similarly, mixed empirical results have been documented in studies on U.S. unemployment. Breitung (1994) and Hatanaka (1996) find non-stationarity in U.S. unemployment, while Nelson \& Plosser (1982), Perron (1988) and Phillips \& Xiao (1998) report evidence in favor of stationarity. It appears that the dynamics of UE change across regions, countries (in the same region), and periods. Hence, we could not avoid carrying unit root tests for both SE and UE. Incorporating the most recent data available for both variables, (1991-2014) we employed several unit root tests. First, we applied the Dickey-Fuller generalized least squares (DF-GLS) test proposed by Elliott, Rothenberg, \& Stock (1996) which is preferred by many time-series econometricians over the more widelyknown tests of Dickey and Fuller or Phillips and Perron (Baum, 2005). The null hypothesis of a unit root is not rejected for neither country for both UE and SE. We then resort to panel unit-root methods to help increase the power of the tests. We employ Im, Pesaran and Shin (1997) extension of the Levin and Lin $(1992,1993)$ test for unit roots in dynamic panels for both variables for the years 1991-2014. Im, Pesaran and Shin (1997) extension offered relaxations of some of the restrictive elements of the Levin and Lin framework, by allowing for heterogeneity in the value of $\rho$; the coefficient of the lagged dependent variable (for a discussion of Levin and Lin and Im, Pesaran and Shin (1997) refer to Banerjee, 1999). 
The null hypothesis $H_{0}: \rho_{i}=0$ for all i, was tested employing Stata's -xtunitroot- command with its -ips- option (Bornhorst et al. 2007). The test results for the SE and UE indicate that both variables contain unit roots, i.e. the null hypothesis that all panels contain unit roots cannot be rejected. The unit root test was performed again on the first differences of the SE and UE variables. The results confirm that both variable are $I(1)$.

\section{Co-integration test}

We can now conduct a co-integration test between SE and UE. The literature on cointegration tests in panel data has taken two main directions. The first assumes as its null hypothesis that there is no co-integration, while the second takes the existence of cointegration as its null hypothesis. We follow the first approach which is taken from Pedroni (1999), whose formulation allows for "considerable heterogeneity in the panel, since heterogeneous slope coefficients, fixed effects and individual specific deterministic trends are all permitted" (Banerjee, 1999 P.617). Specifically, we employ Engle-Granger (EG) test for co-integration in Stata 14.0 (Schaffer, 2010), a two-step residual-based test. The EG test requires the error terms to be serially independent. If this is not the case, lags of the first difference of the residual can be included in the second (test) regression so that the residuals in that regression appear serially uncorrelated. A rejection of the null is an evidence that the residual is stationary, i.e., that the variables are indeed cointegrated. Of the 47 countries in our sample, 43 demonstrated significant co-integration between the SE and UE (for Colombia, Mexico, Venezuela and Russia the null was not rejected and accordingly they had to be removed from the sample).

\section{Dynamic panel - error correction models}

Our emphasis here is on obtaining consistent and efficient estimates of the parameters in a long-term relationship. We therefore employed an autoregressive distributed lag (ARDL) model. Based on Pesaran, Shin and Smith (2001), the dynamic heterogeneous panel regression can be incorporated into the error correction model by using the ARDL model, which allows for rich dynamics in the sense that the dependent variable adapts to changes in the explanatory variables.

We note that while the GMM-difference and system estimators (Arellano and Bond 1991 and Arellano and Bover 1995, respectively) are suitable for large N, small T panels (Eberhardt 
2012), they are unable to capture the long-run dynamics and therefore, were not used in this study.

The $\operatorname{ARDL}\left(p, q_{1}, q_{2}, \ldots q_{k}\right)$ model, where $p$ is the lag of the dependent variable and $q_{j}$ is the lag of the independent variables $(j=1,2, \ldots, k)$ can be stated as follows (Loayza and Ranciere 2006): Assume an $\operatorname{ARDL}\left(p, q_{1}, q_{2}, \ldots q_{k}\right)$ dynamic panel specification of the form:

$$
S E_{i t}=\sum_{j=1}^{p} \lambda_{i j} S E_{i, t-j}+\sum_{j=0}^{q} \delta^{\prime}{ }_{i j} X_{i, t-j}+\mu_{i}+\epsilon_{i t}
$$

where $\mathrm{i}=1,2, . ., \mathrm{N}$ is an index for countries; $\mathrm{t}=1,2, . \mathrm{T}$ is a time index; $\mathrm{X}_{\mathrm{it}}$ is a $\mathrm{k} \times 1$ vector of explanatory variables, $\delta_{i t}$ are the $\mathrm{k} \times 1$ coefficient vectors; $\lambda_{i j}$ are scalars; and $\mu_{i}$ is the country-specific effect. If the variables in (1) are, for example, $I(1)$ and cointegrated, then the error term is an $I(0)$ process for every i. A principal feature of cointegrated variables is their responsiveness to any deviation from long-run equilibrium. This feature implies an error correction model in which the short-term dynamics of the variables in the system are influenced by the deviations from equilibrium. Thus, for estimation purpose, it is common to re-parameterize (1) into the error correction equation:

$$
\Delta S E_{i t}=\sum_{j=1}^{p-1} \lambda^{*}{ }_{i j} \Delta S E_{i, t-j}+\sum_{j=0}^{q-1} \delta^{*}{ }_{i j} \Delta X_{i, t-j}+\phi_{i}\left(S E_{i, t-1}-\theta_{i}{ }^{\prime} X_{i t}\right)+\mu_{i}+\epsilon_{i t}
$$

Where $\phi_{i}=-\left(1-\sum_{j=1}^{p} \lambda_{i j}\right), \theta_{i}=\sum_{j=0}^{q} \delta_{i j} /\left(1-\sum_{k} \lambda_{i k}\right), \quad \lambda^{*}{ }_{i j}=-\sum_{m=j+1}^{p} \lambda_{i m}, \quad \mathrm{j}=1$, $2, \ldots, \mathrm{p}-1$, and $\delta^{*}{ }_{i j}=-\sum_{m=j+1}^{q} \delta_{i m} \quad j=1,2, \ldots, q-1$.

The vector $\theta_{i}$, is of particular importance as it contains the long-run relationships between the variables. The parameter $\phi_{i}$ measures the error-correcting speed of adjustment; if $\phi_{i}=0$, then there would be no evidence for a long-term relationship. This parameter is expected to be significantly negative under the prior assumption that the variables show a return to a longterm equilibrium. Stated differently, having significantly negative estimate of $\phi_{i}$ is considered as evidence of a long-run cointegrated relationship among all the variables.

The ARDL approach may be applied to time series variables irrespective of whether they are $I(0), I(1)$ or mutually cointegrated (Pesaran, Shin and Smith 1999, chap. 4). Other advantage of the ARDL model is that efficient cointegration relationships can be determined even with small samples (Ghatak and Siddiki, 2001). Finally, the ARDL model—and especially its mean group (MG) and pooled mean group (PMG) estimators-provides consistent coefficients despite possible endogeneity because it includes lags of dependent and independent variables (Pesaran et al. 1999). 
We tested three ARDL estimators: the MG of Pesaran and Smith (1995), the PMG, and the dynamic fixed effect (DFE) estimators developed by Pesaran et al. (1999). All three estimators are computed by maximum likelihood. The main characteristic of the $P M G$ estimator is that it allows for the short-term coefficients (including the intercepts, the speed of adjustment to the long-term equilibrium values, and the error variances) to be heterogeneous over countries, whereas the long-term slope coefficients are restricted to be homogeneous across countries. The mean group (MG) estimator, introduced by Pesaran and Smith (1995), is based on estimating separate regression for each country and calculating the coefficients as unweighted means of the individual countries. This does not impose any restrictions, as it allows all coefficients to vary and be heterogeneous in the long-run and the short run. This approach was not used since the necessary condition for its consistency and validity is to have a large enough time-series dimension of the data, which we do not have here. The DFE is similar to the PMG estimator in that it constrains the slope coefficient and error variances to be equal across all countries in the long-run. It further restricts the speed of adjustment coefficient and the short-run coefficient to be equal.

The choice between the estimators is related to the general trade-off between consistency and efficiency; estimators that impose cross-country constraints (such as the DFE and, to a lesser extent, the PMG) dominate the heterogeneous estimators in terms of efficiency if the restrictions are indeed valid. Otherwise, the restricted estimators are inconsistent. In particular, imposing parameter homogeneity, when it is not valid, leads to downward-biased estimates of the speed of adjustment in dynamic models (Robertson and Symons 1992, Pesaran and Smith 1995). The consistency of the PMG and DFE estimators was determined by employing the joint Hausman test.

\section{III.3. Variables}

The dependent variable in our study is the size of the shadow economy measured as a percentage of the GDP (denoted by SE). Our main independent variable is the unemployment rate. The set of controls is drawn from the literature on shadow economy (e.g. Schneider, 1994, Dreher, \& Schneider, 2010; Enste, 2010; D’Hernoncourt \& Méon, 2012; Buehn and Schneider 2013; Buehn et al. 2013; Torgler \& Schneider 2009; Schneider 2015). However, as we deal with panel data, we were very limited in our choice of variables; we could use only those variables with long enough time span, without compromising on the reliability of the data source. Due to their high reliability and the standardized methods employed in their 
calculation, the following variables were employed: GDP per capita, sub-index of the Labor Market Regulation index by Fraser institute, Control of Corruption index as measured by the World Bank, and the Tax Burden also measured by the World Bank. All variables have long enough annual time series. We opted to use another variable: Trust (D'Hernoncourt \& Méon, 2012). This variable reflects the extent to which people in the society believe that other people can be trusted, and was found to be associated with the size of the SE (D'Hernoncourt \& Méon 2012). However, data on 'Trust' across societies is generated by the World Value Survey via surveys, which were administered in five waves between 1981 and 2008. Due to the lack of sufficient data over our sample period, we were forced to give up the use of this variable.

Table 3.1 below gives a full description of all the variables and the data sources employed to collect them. S3 provides the descriptive statistics of these variables per country.

Table 3.1 Variables used in this study.

\begin{tabular}{|c|c|c|}
\hline Variable & Description & Source of data \\
\hline $\begin{array}{l}\text { Shadow } \\
\text { Economy (SE) }\end{array}$ & $\begin{array}{l}\text { Size of the shadow economy as a } \\
\text { percentage of GDP. }\end{array}$ & $\begin{array}{l}\text { For the period 1989-1998, data was obtained } \\
\text { from Schneider (2002); for the period 1999- } \\
2007 \text {, data was obtained from Schneider, } \\
\text { Buehn, and Montenegro (2007); for the } \\
\text { period 2007-2013, data was obtained from } \\
\text { Schneider (2013). }\end{array}$ \\
\hline Unemployment & Annual unemployment rate & World Bank and OECD data \\
\hline GDP & $\begin{array}{l}\text { GDP per capita in PPP international } \\
\text { dollars. }\end{array}$ & World Bank Development Indicators. \\
\hline $\begin{array}{l}\text { Labor Market } \\
\text { Regulations }\end{array}$ & $\begin{array}{l}\text { Labor market regulations' sub-index: } \\
\text { Hiring regulations \& minimum wage. } \\
\text { The higher this index is, the lower } \\
\text { are the barriers to freely entered into } \\
\text { agreements }\end{array}$ & $\begin{array}{l}\text { Economic Freedom of the World, annual } \\
\text { reports } 2015 \text {, The Fraser Institute }\end{array}$ \\
\hline $\begin{array}{l}\text { Corruption } \\
\text { Control }\end{array}$ & $\begin{array}{l}\text { Reflects perceptions of the extent to } \\
\text { which public power is exercised for } \\
\text { private gain. Include both petty and } \\
\text { grand forms of corruption, as well as } \\
\text { "capture" of the state by elites and }\end{array}$ & $\begin{array}{l}\text { World Bank, Worldwide Governance } \\
\text { Indicators over the period 1996-2014, for six } \\
\text { dimensions of governance. } \\
\text { http://info.worldbank.org/governance/wgi/i } \\
\text { ndex.aspx\#home, produced by: }\end{array}$ \\
\hline
\end{tabular}




\begin{tabular}{|l|l|l|}
\hline & $\begin{array}{l}\text { private interests. Ranges from -2.5 to } \\
\text { 2.5. Higher values correspond to } \\
\text { better governance, in this case, better } \\
\text { control of corruption. }\end{array}$ & $\begin{array}{l}\text { Daniel Kaufmann, Natural Resource } \\
\text { Governance Institute (NRGI) and Brookings } \\
\text { Institution and Aart Kraay, World Bank } \\
\text { Development Research Group }\end{array}$ \\
\hline Tax Burden & Tax revenue (\% of GDP) & $\begin{array}{l}\text { World Development Indicators, the World } \\
\text { Bank }\end{array}$ \\
\hline
\end{tabular}

\section{Estimation results}

We present several specifications of the error correction model. All estimations are conducted with -xtpmg- routine in Stata, which fits pooled-mean group, mean group, and dynamic fixed effects panel data models (Blackburne \& Frank, 2007). The first specification (Table 4.1) includes only our two main variables of interest. While it seems unreasonable to assume short-term homogeneity, i.e. to impose equality on the slope coefficients and error variances across all countries in the short-run, we do test our first specification with all three estimators. As for the ARDL structure, based on the Schwartz Bayesian criterion we impose the following lag structure $(1,1)$ for the SE and the UE rate respectively.

Table 4.1: Error correction model, dependent variable: Shadow Economy

\begin{tabular}{lccc}
\hline & MG & PMG & DFE \\
\hline Long run & & & \\
$\Delta$. Unemployment & 2.808 & $5.447^{* * *}$ & $0.554^{* *}$ \\
& $(1.50)$ & $(4.93)$ & $(2.32)$ \\
\hline Short run & & & \\
Error correction & $-0.102^{* * *}$ & $-0.0141^{* *}$ & $-0.0783^{* *}$ \\
& $(-4.12)$ & $(-2.22)$ & $(-2.35)$ \\
& & & \\
$\Delta$. Unemployment & $0.0483^{*}$ & 0.0465 & $0.0431^{* * *}$ \\
& $(1.72)$ & $(1.58)$ & $(3.24)$ \\
Cons & & & \\
& $3.094^{* * *}$ & 0.0916 & $1.741^{* *}$ \\
\hline Housman test & $(3.96)$ & $(0.52)$ & $(2.19)$ \\
\multicolumn{1}{c}{ Countries } & 47 & $1.74^{(1)}$ & $3.09^{(2)}$ \\
\hline
\end{tabular}

Note: *,**, and *** indicate significance at $10 \%, 5 \%$, and $1 \%$.

(1) Ho: difference between coefficients of the MG and PMG are not systematic is not rejected. PMG is consistent and efficient

(2) Ho: difference in coefficients of the PMG and DFE are not systematic, is rejected. 
According to Hausman test we cannot reject the null hypothesis of the homogeneity restriction on the regressors in the long run, which means that PMG is a more efficient estimator than either MG or DFE. We see clear evidence for long-term relationship; the error correction term falls between -1 and 0 and is significant. We also observe positive relationships between the SE and UE in the long-run in all models, and positive significant short-run relationships in the MG and DFE models.

Table 4.2 describes the estimation results of several more specifications, each includes additional covariates. All models are estimated with the PMG estimator.

As for the ARDL structure we impose the common lag structure $(1,1,1,1,1)$ for the SE and the UE rate, GDP, Tax burden, Labor market regulations and Control of corruption respectively.

Table 4.2: Error correction model (PMG), dependent variable: Shadow Economy

\begin{tabular}{|c|c|c|c|c|}
\hline Long-run & (1) & (2) & (3) & (4) \\
\hline Unemployment & $\begin{array}{r}8.083^{* * * *} \\
(10.58)\end{array}$ & $\begin{array}{r}2.654^{* * * *} \\
(4.73)\end{array}$ & $\begin{array}{r}1.691^{* * * *} \\
(8.08)\end{array}$ & $\begin{array}{r}1.626^{* * * *} \\
(11.86)\end{array}$ \\
\hline GDP & $\begin{array}{r}-1.501^{* * *} \\
(-6.77)\end{array}$ & $\begin{array}{r}-1.874^{* * * *} \\
(-4.12)\end{array}$ & $\begin{array}{r}-0.284^{* *} \\
(2.46)\end{array}$ & $\begin{array}{r}-0.206^{* * *} \\
(-4.39)\end{array}$ \\
\hline Tax burden & & $\begin{array}{r}2.079^{* * *} \\
(4.41)\end{array}$ & $\begin{array}{r}0.666^{* * *} \\
(6.95)\end{array}$ & $\begin{array}{r}0.699^{* * *} \\
(10.85)\end{array}$ \\
\hline \multirow{2}{*}{$\begin{array}{l}\text { Labor market } \\
\text { regulations }\end{array}$} & & & $-0.310^{* * *}$ & -0.0255 \\
\hline & & & $(-4.95)$ & $(-1.63)$ \\
\hline Corruption control & & & & $\begin{array}{r}-0.106^{* *} \\
(-2.02)\end{array}$ \\
\hline Error correction & $\begin{array}{r}-0.0058^{* * * *} \\
(-2.89)\end{array}$ & $\begin{array}{r}-0.0103^{* *} \\
(-2.09)\end{array}$ & $\begin{array}{r}-0.0213^{\text {** }} \\
(-2.43)\end{array}$ & $\begin{array}{r}-0.0467^{*} \\
(-1.95)\end{array}$ \\
\hline $\begin{array}{l}\text { No. of } \\
\text { countries }\end{array}$ & 46 & 20 & 20 & 19 \\
\hline
\end{tabular}

The results indicate that in all specifications, the error correction term is negative and falls in the range of -1 and 0 . We can also see that the more explanatory variables we include in the model, the speed of adjustment to long-run equilibrium increases. Unemployment (UE) has a 
positive and insignificant impact on the size of the shadow economy in the long-run in all specifications and no impact in the short-run (except specification 2 in which it is positive and weakly significant -at 10\%). Further, with the inclusion of each explanatory variable, the long-term impact of UE on the SE decreases, which is a reasonable outcome. Income, as measured by GDP per capita, has negative and significant impact on the SE in all specifications in the long and short-run. Its impact also decreases with the inclusion of additional explanatory variables. In line with the results of previous studies, Tax burden, which is the tax revenue as a percentage of GDP, has a significant impact on SE in the longrun, implying that with heavier tax burden, the incentive for tax evasion increases. Short-term impact of Tax burden is insignificant. The index Labor market regulation, which refers to the extent by which there exist barriers to freely hiring and firing workers, is negative and significant (specification 3) in the long-run, implying that the less regulated the labor market is - the less likely it is that workers will enter the underground economy. Finally, as expected, the impact of the index control of corruption is negative and significant in the long-run (specification 4) implying that the size of the shadow economy decreases as the country exercises better control of corruption.

Next, we examine to what extent the above findings vary with the extent of job market regulation. Re-estimating specification (4) in Table 4.2 for two sub-samples, free labor market countries (specification 2 in Table 4.3), and countries with stringent labor market regulations (specification 1 in Table 4.3). We did not include the variable Labor market regulations in these specifications as its variability in each sub-sample is relatively small.

Table 4.3: Error correction model, dependent variable: Shadow Economy countries

\begin{tabular}{lll}
\hline & $\begin{array}{l}\text { (1) Non- free labor } \\
\text { markets }\end{array}$ & \multicolumn{1}{c}{$\begin{array}{l}\text { (2) Free labor } \\
\text { markets }\end{array}$} \\
\hline $\begin{array}{l}\text { Long-run } \\
\text { Unemployment }\end{array}$ & $\begin{array}{l}2.220^{* * *} \\
(8.88)\end{array}$ & $\begin{array}{l}0.596^{* * *} \\
(4.18)\end{array}$ \\
& $\begin{array}{l}\text {-2.435 } \\
(-5.19)\end{array}$ & $-0.323^{* * * *}$ \\
GDP & $(-6.29)$ \\
& $\begin{array}{l}3.209^{* * *} \\
(5.40)\end{array}$ & $1.603^{* * *}$ \\
Tax burden & $(12.12)$ \\
& 0.713 & $-0.639^{* * *}$ \\
Control corrupt & $(1.61)$ & $(-7.76)$
\end{tabular}




$\begin{array}{lll}\text { Error correction } & -0.0110^{*} & -0.0325^{*} \\ (-1.85) & (-1.85)\end{array}$

No. of countries 23 13

$t$ statistics in parentheses

${ }^{*} p<0.10,{ }^{* * *} p<0.05,{ }^{* * *} p<0.01$

We can see that in countries with less stringent job market regulation the long-run impacts of both Unemployment and GDP, while positive and significant, are much smaller than in heavily regulated countries. So is the impact of Tax burden. Yet, what is more striking is the results of the error correction terms. In economies with relatively high degree of freedom to hire and fire workers, the speed of adjustment to long-time equilibrium is larger by a factor of 3 than in regulated labor markets countries.

\section{Summary and concluding remarks}

In this paper we theoretically as well as empirically investigate the positive relation between the unemployment rate and the shadow economy. The main research question is that the shadow economy acts as a buffer, absorbing the workers from the official economy that were laid-off due to negative job market shocks. In our paper we concentrate on the question, whether this absorption is temporary or permanent. In other words, do workers, who switch to the unofficial sector following adverse shocks, switch back to be active in the official job market or do they stay "locked in" in the unofficial sector?

To investigate this theoretically, we develop a simple model, in which we analyze the conditions under which a stable and long-run relationship between unemployment and a shadow economy occurs. Our model leads to two core hypotheses:

(1) The unemployment rate and the shadow economy are bound to a long-run equilibrium relationship by an error-correction mechanism, ceteris paribus.

(2) The speed of adjustment back to equilibrium is greater in economies with looser job market regulation, compared with countries where the regulation of the employeremployee relationship is stricter.

Our empirical results strongly confirm both hypotheses:

(1) There is a long-run relationship between unemployment and the size of the shadow 
economy and

(2) The speed of adjustment back to long-run equilibrium following temporary shocks is shown to be three times faster in countries with looser job market regulation, compared with countries with stricter regulation.

Both hypotheses have important policy implications. While the first of them may deliver a positive message, implying that the growth of the unofficial sector is bounded and that laidoff workers do eventually return to the official job market (even if temporarily drawn to the unofficial sector), the second hypothesis points both to the drawn-out nature of the process of moving back from the shadow economy and the strong dependence of this adjustment back to equilibrium on job market regulation. We finally conclude that the stricter job market regulation is, the harder it is to switch back from the unofficial to the official sector. In countries with a freer labor market, the speed of adjustment to long-time equilibrium is larger by a factor of 3 than in regulated labor market countries. An important policy conclusion is that strict labor market regulation may be advantageous for those who are employed, but the opposite is true for the unemployed. 


\section{References}

Arellano, M., \& Bover, O. (1995). Another look at the instrumental variable estimation of error-components models. Journal of econometrics, 68(1), 29-51.

Arellano, M., \& Bond, S. (1991). Some tests of specification for panel data: Monte Carlo evidence and an application to employment equations. The review of economic studies, 58(2), 277-297.

Bajada, C., \& Schneider, F. (2009). Unemployment and the Shadow Economy in the OECD. Revue économique, 60(5), 1033-1067.

Banerjee, Anindya. "Panel data unit roots and cointegration: an overview." Oxford Bulletin of economics and Statistics 61.S1 (1999): 607-629.

Baum, C.F. Stata: The language of choice for time-series analysis? The Stata Journal (2005) 5, Number 1, pp. 46-63, Boston College

Blackburne, E. F., \& Frank, M. W. (2007). Estimation of nonstationary heterogeneous panels. Stata Journal, 7(2), 197.

Buehn, A., \& Schneider, F. (2013). Shadow Economies in highly developed OECD countries: What are the driving forces? (No. 2013-17).

Buehn, Andreas, Christian Lessmann, and Gunther Markwardt. "Decentralization and the shadow economy: Oates meets Allingham-Sandmo."Applied Economics 45.18 (2013): 25672578.

Bornhorst, Fabian and Baum, Christopher, (2007), IPSHIN: Stata module to perform ImPesaran-Shin panel unit root test, http://EconPapers.repec.org/RePEc:boc:bocode:s419704.

Buehn, A., Lessmann, C., \& Markwardt, G. (2013). Decentralization and the shadow economy: Oates meets Allingham-Sandmo. Applied Economics, 45(18), 2567-2578.

Breitung, J. (1994). Some simple tests of the moving-average unit root hypothesis. Journal of time series analysis, 15(4), 351-370.

Camarero, Mariam, and Cecilio Tamarit. "Hysteresis vs. natural rate of unemployment: new evidence for OECD countries." Economics Letters 84.3 (2004): 413-417.

Chang, T., Lee, K. C., Nieh, C. C., \& Wei, C. C. (2005). An empirical note on testing hysteresis in unemployment for ten European countries: panel SURADF approach. Applied Economics Letters, 12(14), 881-886. 
Christopoulos, D. K., \& León-Ledesma, M. A. (2007). Unemployment hysteresis in EU countries: what do we really know about it? Journal of Economic Studies, 34(2), 80-89.

Cooper, R., and John, A. (1988). Coordinating Coordination Failures in Keynesian Models. The Quarterly Journal of Economics Vol. 103 (3), pp. 441-463

Dell'Anno, R., Solomon, O.H. (2008). Shadow Economy and Unemployment Rate in U.S.A. Is there a structural relationship? An empirical analysis. Applied Economics 40 (19), pp.25372555 .

Demetriades, P., \& Hook Law, S. (2006). Finance, institutions and economic development. International Journal of Finance and Economics, 11(3), 245.

D'Hernoncourt, J., \& Méon, P. G. (2012). The not so dark side of trust: Does trust increase the size of the shadow economy?. Journal of economic behavior \& organization, 81(1), 97121.

Dreher, A., \& Schneider, F. (2010). Corruption and the shadow economy: an empirical analysis. Public Choice, 144(1-2), 215-238.

Elliot, B. E., Rothenberg, T. J., \& Stock, J. H. (1996). Efficient tests of the unit root hypothesis. Econometrica, 64(8), 13-36.

Enste, D. H. (2010). Regulation and shadow economy: empirical evidence for 25 OECDcountries. Constitutional Political Economy, 21(3), 231-248.

Ghatak, S., \& Siddiki, J. U. (2001). The use of the ARDL approach in estimating virtual exchange rates in India. Journal of Applied statistics, 28(5), 573-583.

Hatanaka, M. (1996). Time-series-based econometrics: unit roots and co-integrations. OUP Catalogue.

Heckman, J. and Pages, C. (2000). The Cost of Job Security Regulation: Evidence from Latin American Labor Markets. NBER Working Paper No. 7773

Im, K. S., Pesaran, M. H., \& Shin, Y. (1997). Testing for unit roots in heterogeneous panels. Department of Applied Economics, University of Cambridge. mimeo.

Kugler, A. (2000). The Incidence of Job Security Regulations on Labor Market Flexibility and Compliance in Colombia: Evidence from the 1990 Reform. Research Network Working Paper R-393. Washington, D.C., United States: Inter-American Development Bank. 
Levin, A. and Lin, C. F. (1992). 'Unit Root Tests in Panel Data: Asymptotic and Finite Sample Properties', Department of Economics, University of California at San Diego, Discussion Paper No. 92-93 (revised 1993).

Levin, A. and Lin, C. F. (1993). 'Unit Root Tests in Panel Data: New Results', Department of Economics, University of California at San Diego, Discussion Paper No. $93 \pm 56$

Loayza, N. V., \& Ranciere, R. (2006). Financial development, financial fragility, and growth. Journal of Money, Credit and Banking, 1051-1076.

Nelson, C. R., \& Plosser, C. R. (1982). Trends and random walks in macroeconmic time series: some evidence and implications. Journal of monetary economics, 10(2), 139-162.

Pedroni, P. (1999). Critical values for cointegration tests in heterogeneous panels with multiple regressors. Oxford Bulletin of Economics and statistics, 61(s 1), 653-670.

Perron, P. (1988). Trends and random walks in macroeconomic time series: Further evidence from a new approach. Journal of economic dynamics and control, 12(2), 297-332.

Pesaran, M. H., \& Smith, R. (1995). Estimating long-run relationships from dynamic heterogeneous panels. Journal of econometrics, 68(1), 79-113.

Pesaran, M. H., Shin, Y., \& Smith, R. P. (1999). Pooled mean group estimation of dynamic heterogeneous panels. Journal of the American Statistical Association, 94(446), 621-634.

Pesaran, M. H., Shin, Y., \& Smith, R. J. (2001). Bounds testing approaches to the analysis of level relationships. Journal of applied econometrics, 16(3), 289-326.

Phillips, P. C., \& Xiao, Z. (1998). A primer on unit root testing. Journal of Economic Surveys, 12(5), 423-470.

Robertson, D., \& Symons, J. (1992). Some strange properties of panel data estimators. Journal of Applied econometrics, 7(2), 175-189.

Schaffer, M.E. (2010). Egranger: Engle-Granger (EG) and Augmented Engle-Granger (AEG) cointegration tests and 2-step ECM estimation. http://ideas.repec.org/c/boc/bocode/s457210.html

Schneider, F. (1994). Can the shadow economy be reduced through major tax reforms? An empirical investigation for Austria. Public Finance, 49(Supplement), 137-52.

Schneider, F. (ed.) (2011). Handbook on the Shadow Economy. Cheltenham (UK): Edward Elgar Publishing Company. 
Schneider, F. (2015). Size and Development of the Shadow Economy of 31 European and 5 Other OECD Countries from 2003 to 2014: Different Developments?. Journal of SelfGovernance and Management Economics, 3(4), 7-29.

Schneider, F. \& Williams, C.C. (2013). The Shadow Economy. London: Institute of Economic Affairs.

Song, F. M. and F. Wu (1997): "Hysteresis in unemployment: evidence from 48 states", Economic Enquiry, vol. 35, pp. 235-244.

Song, F. M. and F. Wu (1998): "Hysteresis in unemployment: evidence from OECD countries", The Quarterly Review of Economics and Statistics, vol. 38, pp. 181-192.

Torgler, B., \& Schneider, F. (2009). The impact of tax morale and institutional quality on the shadow economy. Journal of Economic Psychology, 30(2), 228-245.

Williams, C.C. \& Schneider, F. (2016). Measuring the Global Shadow Economy: The Prevalence of Informal Work and Labour. Cheltenham (UK): Edward Elgar Publishing Company.

Yitzhaki, S. (1987), "On the excess burden of tax evasion", Public Finance Quarterly 15(2):123-137. 
Appendix

S1: Distribution of SE tipping years for countries' demonstrating inverted U shape

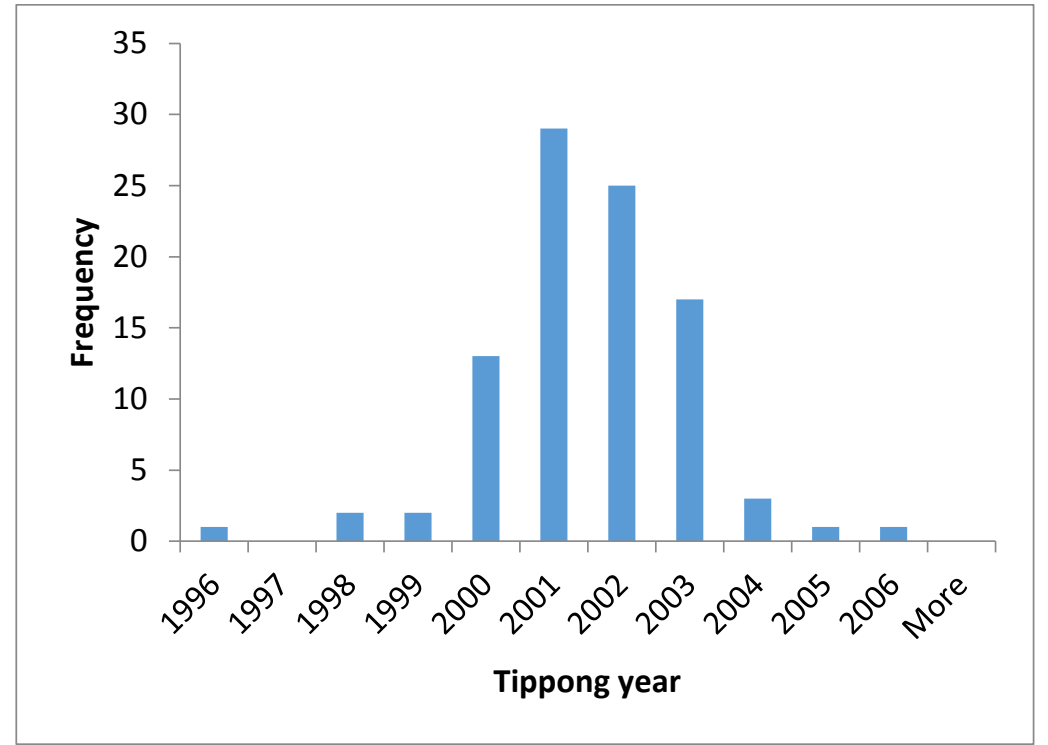

S2: Scatter plot of the SE over time in six geographical regions

Panel A: Scandinavia
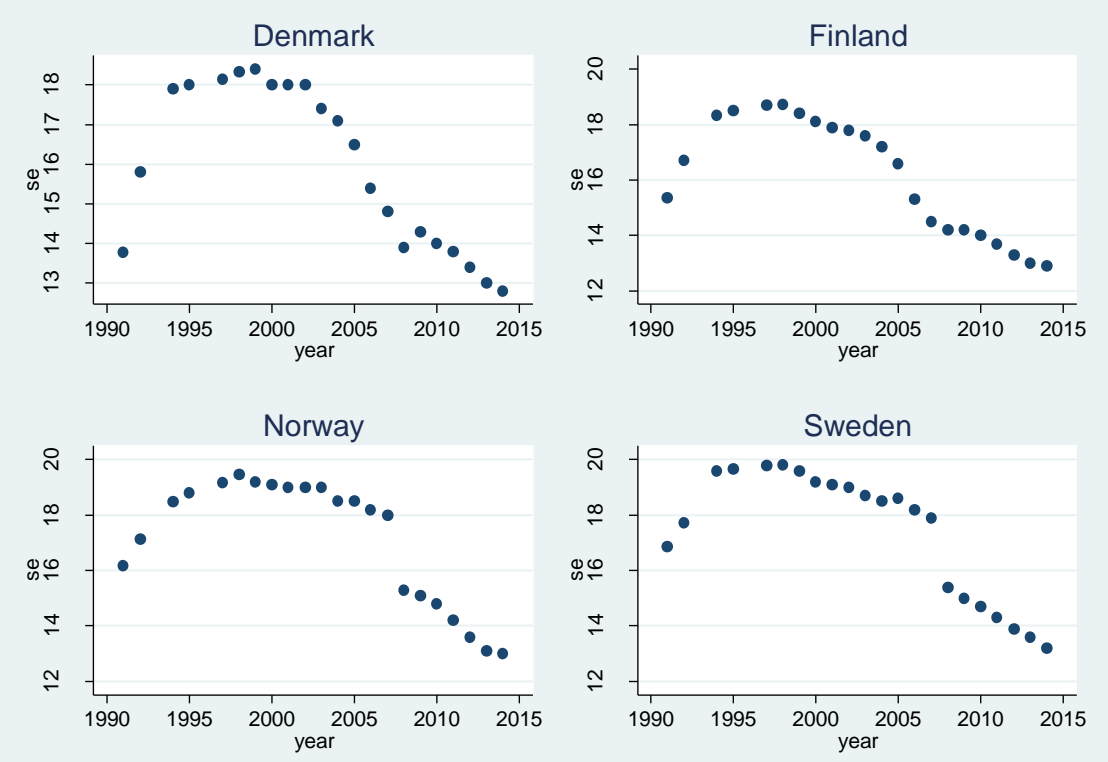


\section{Panel B: Western Europe}
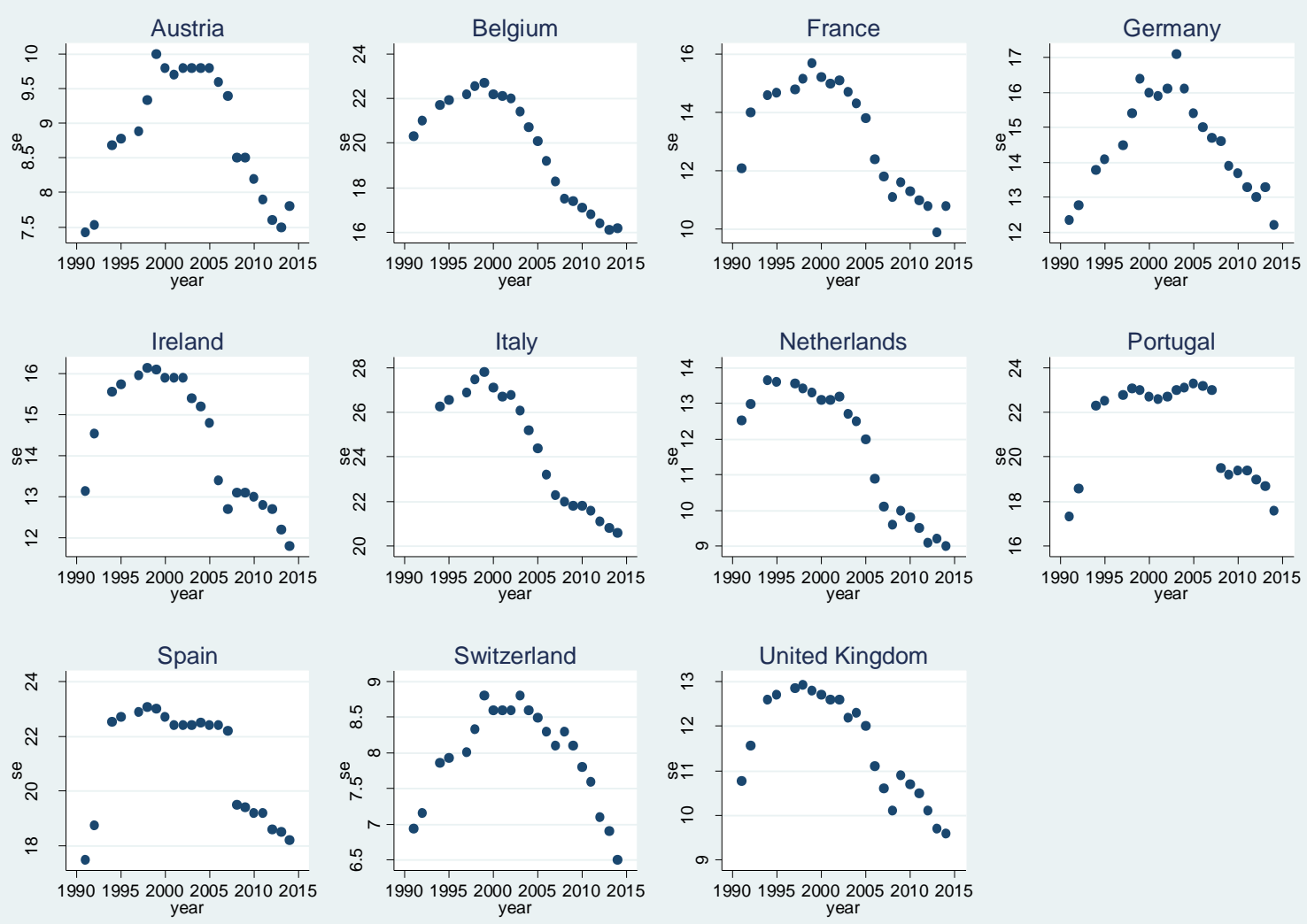

Panel C: North America

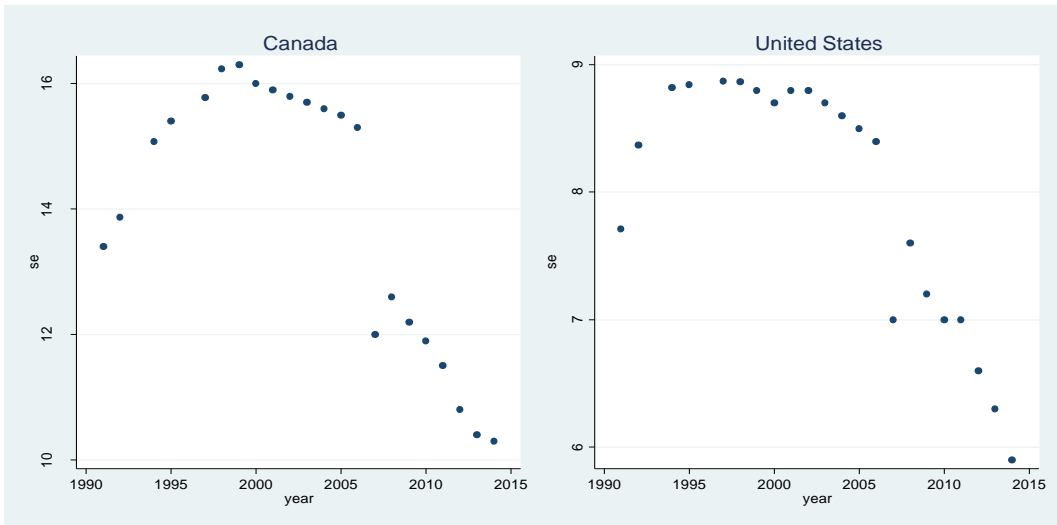


Panel D: Eastern Europe
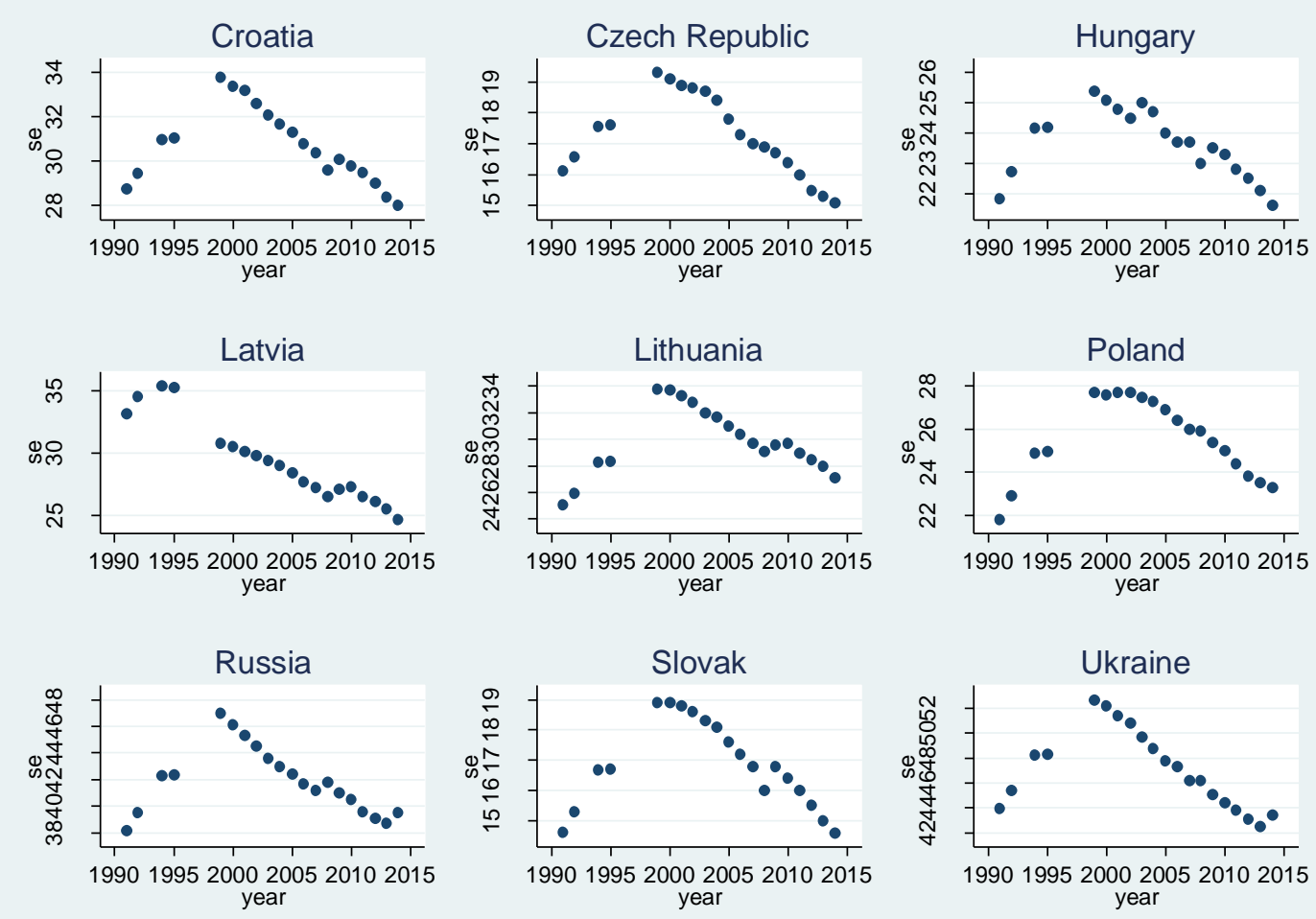

Panel E: Southeastern Europe

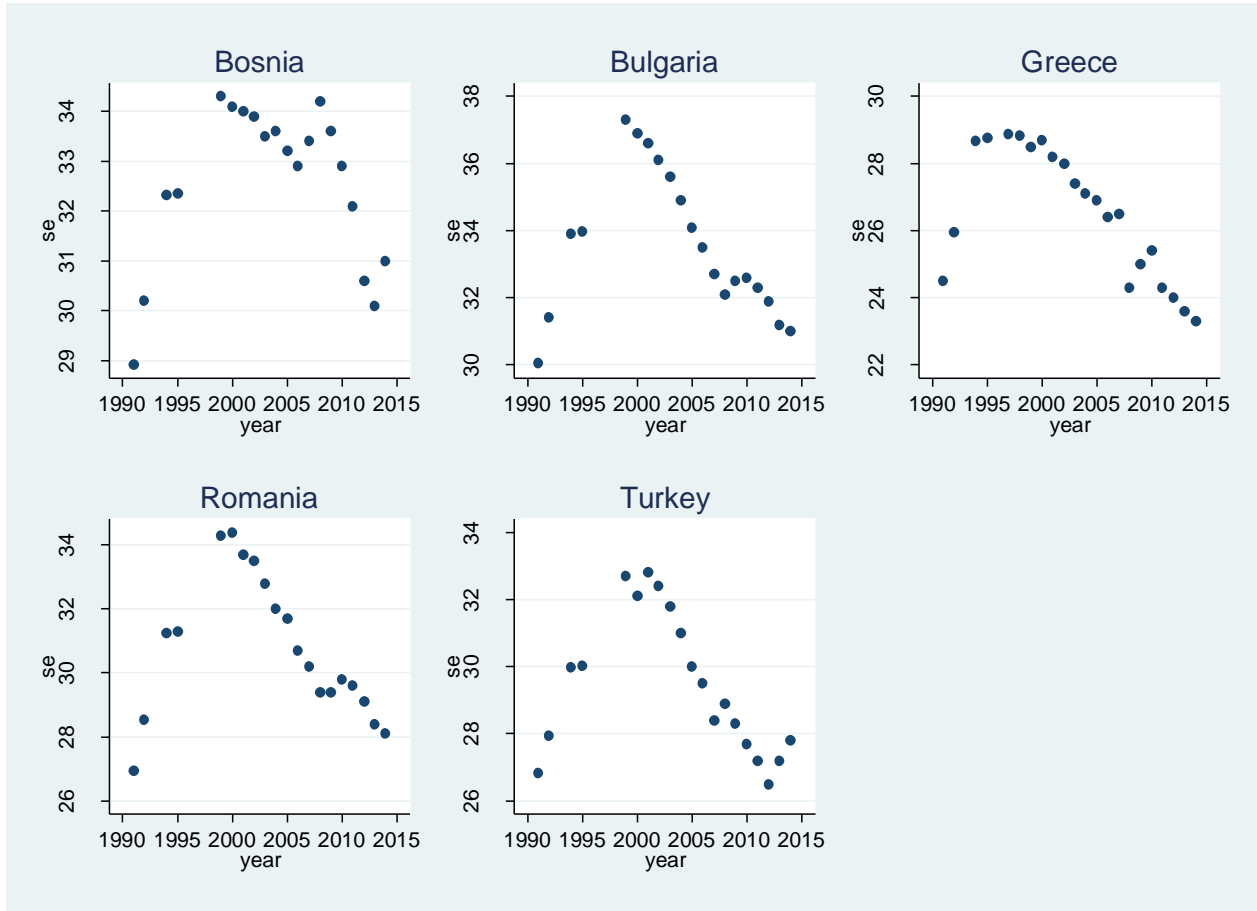


S3: Graphical illustration of this co-movement for six regions.
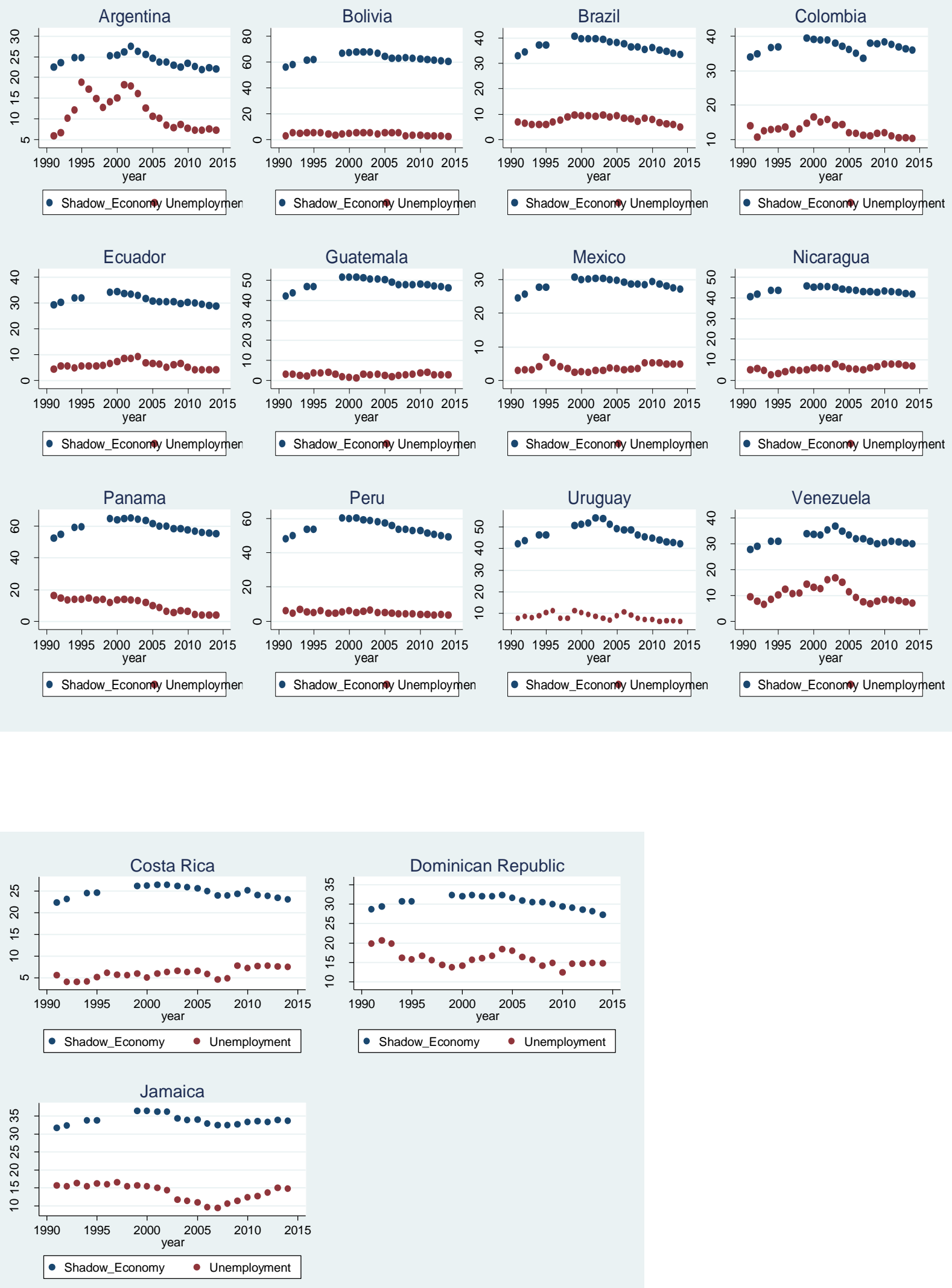

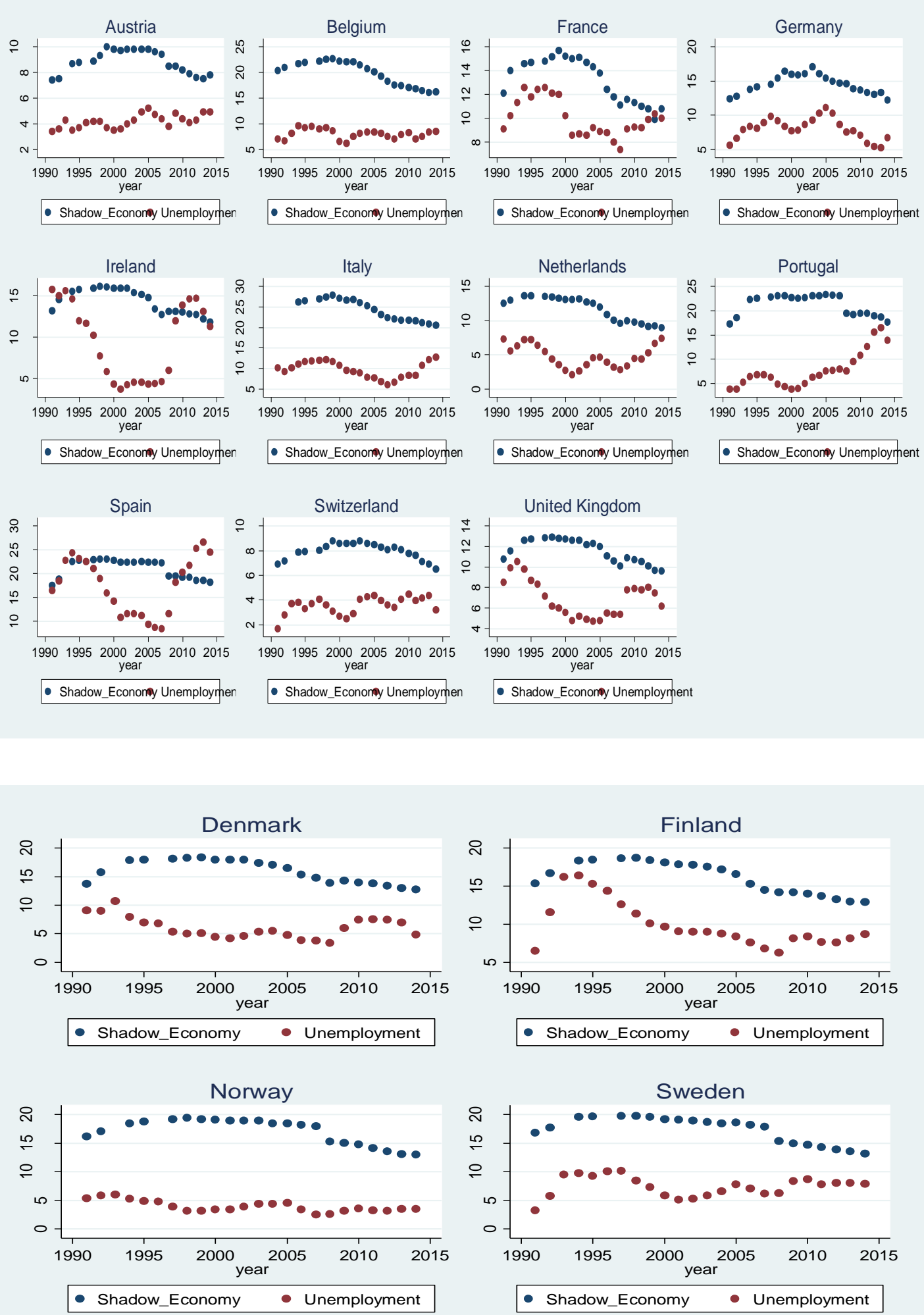
Croatia

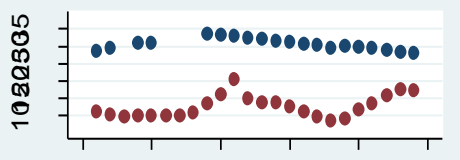

199019952000200520102015 year

- Shadow_EconomyUnemploymen
Czech Republic

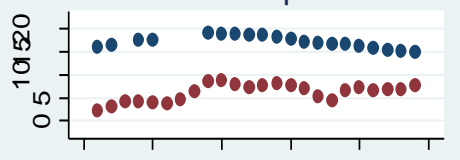

199019952000200520102015 year

- Shadow_EconomyUnemployment
Hungary

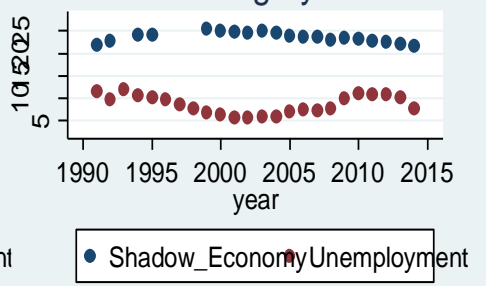

Poland
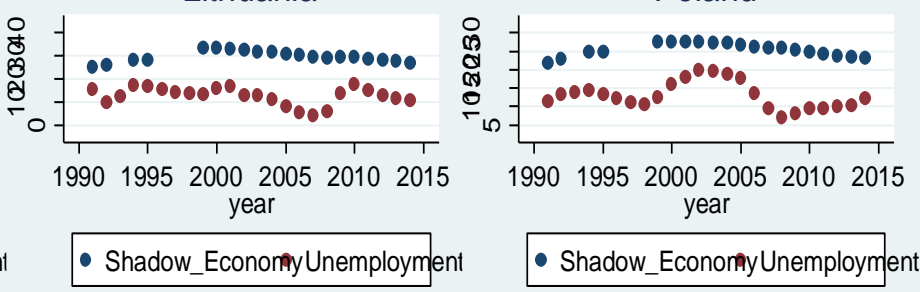

Russia

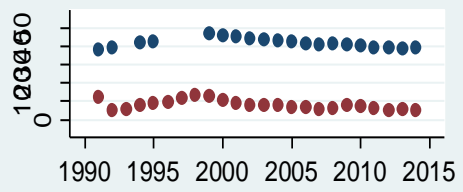
year

- Shadow_EconomyUnemploymen
Slovak

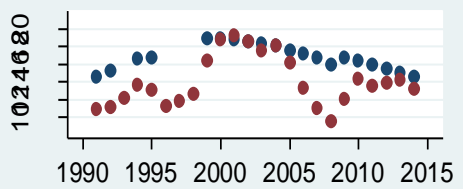
year

- Shadow_EconomyUnemployment
Ukraine

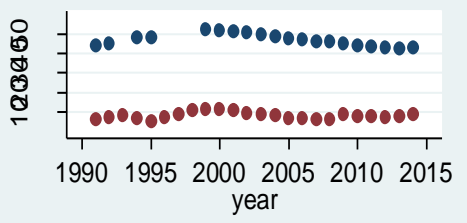
year

- Shadow_EconomyUnemployment
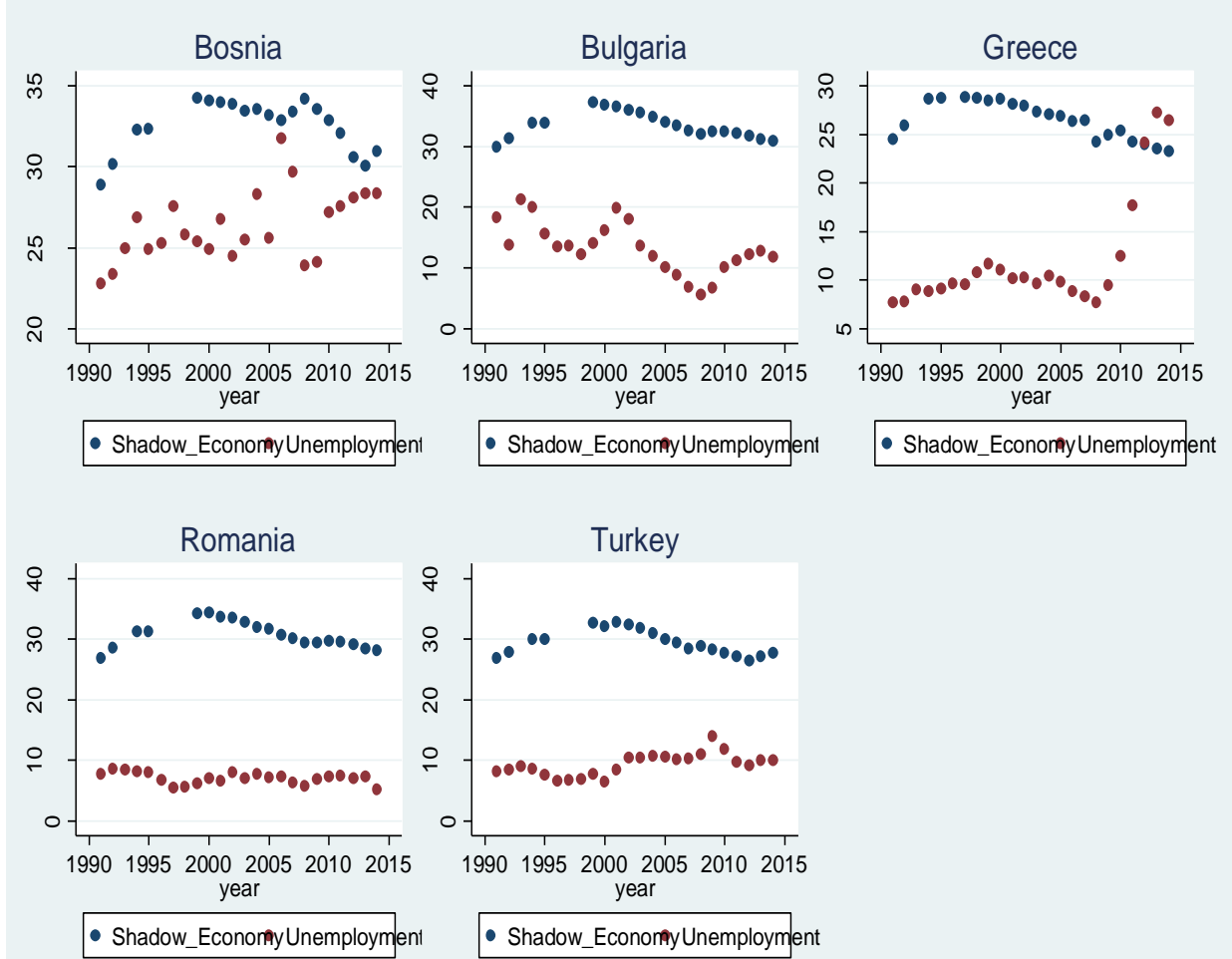
S4: Means and standard deviations of the variables employed in the regressions analyses by country for the years 1991-2014.

\begin{tabular}{|c|c|c|c|c|c|c|}
\hline & $\begin{array}{l}\text { Shadow } \\
\text { economy } \\
\text { (Annual \%) }\end{array}$ & $\begin{array}{c}\text { Unemployment } \\
\text { (Annual \%) }\end{array}$ & $\begin{array}{l}\text { GDP Per } \\
\text { capita }\end{array}$ & $\begin{array}{l}\text { Labor } \\
\text { market reg. } \\
\text { (range 1-10) }\end{array}$ & $\begin{array}{l}\text { Tax burden } \\
\text { (Tax revenue } \\
\% \text { of GDP) }\end{array}$ & $\begin{array}{l}\text { Corruption } \\
\text { control } \\
\text { (range -2.5-2.5) }\end{array}$ \\
\hline \multirow[t]{2}{*}{ Argentina } & 24.231 & 11.454 & N/A & 5.127 & 11.4 & -0.412 \\
\hline & (1.50) & (4.19) & & (1.03) & (1.41) & $(0.10)$ \\
\hline \multirow[t]{2}{*}{ Austria } & 8.80 & 4.19 & 32979.14 & 8.52 & 19.24 & 1.71 \\
\hline & $(0.89)$ & $(0.52)$ & (8862.94) & (2.20) & (0.99) & $(0.66)$ \\
\hline \multirow[t]{2}{*}{ Belgium } & 19.97 & 8.03 & 31025.23 & 8.00 & 25.22 & 1.41 \\
\hline & (2.34) & (0.95) & (7766.34) & $(1.81)$ & (0.99) & $(0.11)$ \\
\hline \multirow[t]{2}{*}{ Bolivia } & 63.22 & 4.23 & 4102.15 & 2.35 & 15.20 & -0.46 \\
\hline & (3.12) & (1.09) & (1203.15) & (0.33) & (1.78) & $(0.58)$ \\
\hline \multicolumn{7}{|l|}{ Bosnia and } \\
\hline \multirow[t]{2}{*}{ Herzegovina } & 32.60 & 26.33 & 6097.33 & 3.83 & N/A & -0.34 \\
\hline & (1.50) & (2.15) & (2986.13) & $(0.93)$ & & $(0.10)$ \\
\hline \multirow[t]{2}{*}{ Brazil } & 37.20 & 7.65 & 10616.29 & 2.94 & 13.67 & -0.05 \\
\hline & $(2.26)$ & $(1.45)$ & (2978.30) & (1.21) & (2.29) & $(0.11)$ \\
\hline \multirow[t]{2}{*}{ Bulgaria } & 33.76 & 13.31 & 9679.39 & 6.66 & 18.90 & -0.22 \\
\hline & (2.09) & (4.22) & (4530.32) & (1.94) & (2.41) & (0.19) \\
\hline \multirow[t]{2}{*}{ Canada } & 14.07 & 8.08 & 32087.70 & 8.04 & 13.39 & 1.89 \\
\hline & (2.05) & $(1.58)$ & (8219.11) & (1.76) & (1.08) & $(0.59)$ \\
\hline \multirow[t]{2}{*}{ Columbia } & 37.05 & 12.68 & 8178.85 & 7.65 & 12.79 & -0.16 \\
\hline & (1.62) & (1.77) & (2514.85) & (2.14) & (1.11) & $(0.54)$ \\
\hline \multirow[t]{2}{*}{ Costa Rica } & 24.75 & 6.04 & 9157.75 & 2.24 & 14.06 & 0.50 \\
\hline & (1.16) & (1.19) & (3145.99) & (0.68) & (0.94) & $(0.28)$ \\
\hline \multirow[t]{2}{*}{ Croatia } & 30.89 & 12.57 & 15305.24 & 3.29 & N/A & -0.01 \\
\hline & (1.67) & (3.17) & (4731.81) & $(0.84)$ & & $(0.36)$ \\
\hline \multicolumn{7}{|l|}{ Czech } \\
\hline \multirow[t]{2}{*}{ Republic } & 17.40 & 6.23 & 20333.93 & 7.01 & 14.53 & 0.33 \\
\hline & (1.27) & (1.87) & $(6616.00)$ & (1.37) & (1.45) & $(0.15)$ \\
\hline \multirow[t]{2}{*}{ Denmark } & 16.07 & 6.11 & 32362.84 & 8.64 & 31.49 & 2.31 \\
\hline & (2.01) & (1.90) & (8531.32) & (2.35) & (1.83) & $(0.54)$ \\
\hline \multicolumn{7}{|l|}{ Dominican } \\
\hline \multirow[t]{2}{*}{ Republic } & 30.60 & 16.03 & 7610.30 & 4.72 & 13.57 & -0.45 \\
\hline & (1.49) & (2.06) & (2958.16) & $(0.97)$ & (1.17) & $(0.75)$ \\
\hline \multirow[t]{2}{*}{ Ecuador } & 31.37 & 5.90 & 7340.69 & 5.08 & 17.97 & -0.83 \\
\hline & (1.73) & (1.41) & (1981.36) & $(0.83)$ & (5.40) & $(0.12)$ \\
\hline \multirow[t]{2}{*}{ Finland } & 16.30 & 9.92 & 29265.80 & 4.88 & 21.14 & 2.18 \\
\hline & (2.09) & (3.01) & (8734.58) & (0.79) & (1.37) & $(0.81)$ \\
\hline \multirow[t]{2}{*}{ France } & 13.28 & 10.02 & 28451.20 & 3.44 & 21.10 & 1.43 \\
\hline & (1.83) & (1.55) & (7043.76) & (0.51) & (1.19) & $(0.21)$ \\
\hline \multirow[t]{2}{*}{ Germany } & 14.47 & 8.01 & 31044.22 & 5.92 & 10.84 & 1.81 \\
\hline & (1.36) & (1.58) & (8208.40) & (1.06) & $(0.44)$ & (0.19) \\
\hline Greece & 26.64 & 12.02 & 22241.53 & 5.42 & 19.95 & 0.36 \\
\hline
\end{tabular}




\begin{tabular}{|c|c|c|c|c|c|c|}
\hline & $(1.91)$ & (5.78) & (5864.58) & $(0.66)$ & (1.32) & (0.53) \\
\hline \multirow[t]{2}{*}{ Guatemala } & 48.30 & 2.82 & 5307.89 & 5.44 & 9.99 & -0.60 \\
\hline & $(2.46)$ & $(0.74)$ & (1217.99) & $(0.37)$ & (1.64) & (0.16) \\
\hline \multirow[t]{2}{*}{ Hungary } & 23.77 & 8.70 & 15410.10 & 7.89 & 21.66 & 0.42 \\
\hline & $(1.10)$ & $(2.06)$ & (5731.30) & (1.79) & (1.19) & (0.33) \\
\hline \multirow[t]{2}{*}{ Ireland } & 14.42 & 9.52 & 32962.91 & 8.16 & 24.90 & 1.50 \\
\hline & $(1.48)$ & (4.59) & (12194.94) & $(1.56)$ & $(4.08)$ & (0.39) \\
\hline \multirow[t]{2}{*}{ Italy } & 24.66 & 9.75 & 28346.84 & 5.55 & 22.10 & 0.39 \\
\hline & $(2.48)$ & (1.97) & (5869.65) & $(1.44)$ & $(0.98)$ & $(0.40)$ \\
\hline \multirow[t]{2}{*}{ Jamaica } & 34.00 & 13.80 & 7194.09 & 8.14 & 26.18 & -0.38 \\
\hline & $(1.37)$ & $(2.30)$ & (1175.28) & $(1.85)$ & (0.99) & $(0.16)$ \\
\hline \multirow[t]{2}{*}{ Japan } & 10.14 & 4.02 & 28357.77 & 8.34 & 9.86 & 1.18 \\
\hline & (1.09) & $(0.94)$ & $(5284.54)$ & $(1.95)$ & (0.78) & (0.48) \\
\hline \multirow[t]{2}{*}{ Latvia } & 29.95 & 12.53 & 13806.69 & 3.29 & 9.23 & 0.17 \\
\hline & $(3.38)$ & (3.14) & (5954.32) & $(1.10)$ & (0.91) & $(0.50)$ \\
\hline \multirow[t]{2}{*}{ Lithuania } & 29.90 & 12.75 & 15092.24 & 6.21 & 53.58 & 0.18 \\
\hline & $(2.40)$ & (3.77) & (7008.01) & $(1.77)$ & (7.34) & $(0.14)$ \\
\hline \multirow[t]{2}{*}{ Mexico } & 28.71 & 3.93 & 11435.29 & 6.21 & 11.27 & -0.26 \\
\hline & $(1.57)$ & $(1.13)$ & $(3206.36)$ & $(1.50)$ & (7.52) & $(0.22)$ \\
\hline \multirow[t]{2}{*}{ Netherland } & 11.83 & 4.81 & 34398.10 & 6.86 & 21.00 & 1.97 \\
\hline & $(1.77)$ & $(1.66)$ & (9995.75) & $(1.46)$ & (0.56) & $(0.73)$ \\
\hline \multirow[t]{2}{*}{ Nicaragua } & 43.60 & 5.83 & 3138.21 & 6.90 & N/A & -0.51 \\
\hline & $(1.34)$ & (1.42) & (921.65) & (1.59) & & (0.69) \\
\hline \multirow[t]{2}{*}{ Norway } & 17.23 & 3.98 & 42234.20 & 4.46 & 27.21 & 1.94 \\
\hline & (2.19) & (0.99) & (16675.39) & $(0.73)$ & $(0.93)$ & (0.77) \\
\hline \multirow[t]{2}{*}{ Panama } & 59.83 & 10.49 & 10526.67 & 2.37 & 11.67 & -0.16 \\
\hline & $(3.67)$ & $(4.14)$ & (4677.37) & $(0.69)$ & $(1.32)$ & $(0.64)$ \\
\hline \multirow[t]{2}{*}{ Peru } & 54.60 & 5.05 & 6729.79 & 4.82 & 14.13 & -0.29 \\
\hline & (3.79) & $(0.96)$ & (2696.13) & $(1.12)$ & $(1.51)$ & $(0.10)$ \\
\hline \multirow[t]{2}{*}{ Poland } & 25.56 & 13.10 & 13607.26 & 7.46 & 16.76 & 0.33 \\
\hline & $(1.73)$ & $(3.67)$ & (6305.54) & $(2.28)$ & $(0.83)$ & $(0.30)$ \\
\hline \multirow[t]{2}{*}{ Portugal } & 21.21 & 7.69 & 20107.47 & 5.23 & 20.08 & 1.07 \\
\hline & $(2.08)$ & (3.69) & (5775.24) & $(1.64)$ & $(0.61)$ & $(0.21)$ \\
\hline \multirow[t]{2}{*}{ Romania } & 30.98 & 7.05 & 10048.21 & 3.39 & 14.45 & -0.21 \\
\hline & $(2.12)$ & $(0.93)$ & $(5612.25)$ & $(0.92)$ & (2.98) & $(0.32)$ \\
\hline \multirow[t]{2}{*}{ Russia } & 42.18 & 8.20 & 12158.11 & 5.58 & 14.71 & -0.89 \\
\hline & $(2.50)$ & $(2.47)$ & $(6884.50)$ & $(1.48)$ & $(1.52)$ & $(0.23)$ \\
\hline \multirow[t]{2}{*}{ Slovak } & 16.93 & 14.04 & 16155.09 & 6.93 & 13.68 & 0.18 \\
\hline & $(1.37)$ & $(2.80)$ & (7275.91) & $(1.41)$ & (1.58) & (0.32) \\
\hline \multirow[t]{2}{*}{ Spain } & 21.08 & 17.37 & 24781.93 & 2.83 & 12.81 & 1.08 \\
\hline & $(1.93)$ & $(5.90)$ & (7185.58) & $(1.25)$ & $(2.78)$ & $(0.31)$ \\
\hline \multirow[t]{2}{*}{ Sweden } & 17.53 & 7.46 & 32372.64 & 6.43 & 20.88 & 2.15 \\
\hline & $(2.27)$ & $(1.76)$ & (8857.95) & $(1.78)$ & $(1.03)$ & $(0.44)$ \\
\hline \multirow[t]{2}{*}{ Switzerland } & 7.95 & 3.59 & 39885.59 & 8.89 & 9.49 & 2.13 \\
\hline & $(0.65)$ & $(0.70)$ & (11021.97) & $(2.03)$ & $(0.29)$ & $(0.06)$ \\
\hline Turkey & 29.67 & 9.31 & 10855.65 & 5.07 & 19.74 & 0.03 \\
\hline & $(2.02)$ & $(1.83)$ & (5026.70) & $(0.91)$ & $(0.86)$ & (0.63) \\
\hline
\end{tabular}




\begin{tabular}{lcccrrr} 
Ukraine & 47.49 & 8.38 & 5920.81 & 5.37 & 15.51 & -0.88 \\
\multirow{2}{*}{ UK } & $(3.12)$ & $(1.69)$ & $(1950.38)$ & $(1.56)$ & $(2.26)$ & $(0.25)$ \\
& 11.62 & 6.94 & 29812.45 & 8.13 & 25.86 & 1.83 \\
USA & $(1.13)$ & $(1.78)$ & $(7517.03)$ & $(1.61)$ & $(0.92)$ & $(0.27)$ \\
\multirow{2}{*}{ Uruguay } & 8.04 & 6.24 & 39460.52 & 8.82 & 10.18 & 1.34 \\
\multirow{4}{*}{ Venezuela } & $(0.95)$ & $(1.61)$ & $(9566.18)$ & $(2.38)$ & $(1.08)$ & $(0.66)$ \\
\multicolumn{4}{r}{$*$} \\
\multirow{2}{*}{ N Number in parentheses present standard deviations, other numbers are means. }
\end{tabular}

